\title{
Placemaking in Informal Settlements: The Case of France Colony, Islamabad, Pakistan
}

\author{
Ramisa Shafqat *, Dora Marinova (D) and Shahed Khan
}

Curtin University Sustainability Policy Institute, Curtin University, Perth, WA 6845, Australia; d.marinova@curtin.edu.au (D.M.); s.khan@curtin.edu.au (S.K.)

* Correspondence: ramisa.malik@gmail.com

check for updates

Citation: Shafqat, R.; Marinova, D.; Khan, S. Placemaking in Informal Settlements: The Case of France Colony, Islamabad, Pakistan. Urban Sci. 2021, 5, 49. https:// doi.org/ $10.3390 /$ urbansci5020049

Academic Editor:

Matheos Santamouris

Received: 9 May 2021

Accepted: 16 June 2021

Published: 20 June 2021

Publisher's Note: MDPI stays neutral with regard to jurisdictional claims in published maps and institutional affiliations.

Copyright: (c) 2021 by the authors. Licensee MDPI, Basel, Switzerland. This article is an open access article distributed under the terms and conditions of the Creative Commons Attribution (CC BY) license (https:// creativecommons.org/licenses/by/ $4.0 /)$.

\begin{abstract}
This paper provides an alternative perspective on urban informal settlements by analysing them as places of rural remnants, reservoirs of regional cultural heritage, and spaces entailing traditional sustainable elements that are brought to the urban realm by rural migrants. These socio-cultural and spatial attributes of a settlement converge under the notion of a "place." Placemaking analysis is thus contended to be appropriate for comprehensive understanding of an informal settlement. The selected case study of France Colony, Islamabad, employs the placemaking methodology framework to investigate sustainability values and practices from the day-to-day living of its inhabitants. Data collected through on-site interviews during transect walks in France Colony are then translated into four maps as a spatio-cultural documentation of the sustainable elements found in the informal settlement. The four maps relate to form and users, activities and amenities, image and characteristics, and access and linkages. This systematic analysis assisted in categorising the sustainability characteristics of the informal settlements according to the three pillars (social, economic, and environmental) of sustainability. The findings show that the organic placemaking, originating from everyday life, values, behaviour, and lifestyle of the informal dwellers, allows for a strong and vibrant resilient community to emerge.
\end{abstract}

Keywords: placemaking; informal settlements; sustainability; resilience; France Colony; Islamabad

\section{Introduction}

Place is created when space - the spatial, physical dimension of a location-is humanised by socio-cultural elements [1,2]. In this study, this process of placemaking is investigated in an informal settlement in Islamabad, Pakistan, namely, France Colony. The socio-cultural influences that modify the space and shape it according to the lifestyle, values, and cultural heritage of informal dwellers are analysed. Thus, the paper focuses on the debate on place and placemaking, which entails a cultural, social, and spatial discourse. Although the notion of place and placemaking is vast, it is only discussed from a sustainability perspective in the context of urban informalities, which are often forgotten.

\subsection{What Is Place}

"[T]o think of an area of the world as a rich and complicated interplay of people and the environment as a place-is to free us from thinking of it as facts and figures" [1] (p. 11).

A place, therefore, is a socio-spatial construct of an area. When looking at a place, exhibited human behaviour, involvement, cultural expression, and values are central elements. According to Friedmann [2] (p. 260), places are "the stuff of stories, part of the little histories of the world." The notion of place emphasises that the social and spatial concerns are analytically inseparable [3]. An individual is not separated from the place, but rather represents the place [4] (p. 43). Cresswell [1] (p. 11) further explains that "space therefore becomes place when human attach meaning to it." Meaning is derived from identity, which is the cultural values and social system of humankind. 


\subsection{Conceptual Understanding of the Placemaking Process}

The initial idea of placemaking originated in urban design theories [5]. Initially it emerged as a top-down approach involving professional architects and urban and physical planners, but in the last few decades its focus has mainly been on community involvement [6]. In fact, placemaking represents a paradigm shift in urban design, planning, and policy that is human-centric and engages the community [7]. Courage [7] argues that community is front and centre in deciding how a place looks and functions, making placemaking an organic process. Schneekloth and Shibley [8] (p. 1) describe the (organic) placemaking (process) as "the way in which all of us as human beings transform the places in which we find ourselves into places in which we live." Placemaking is further explained [2] (p. 259) as a process of appropriating space in order to create a "mirror of self." Thus, in theory, organic or unplanned placemaking is seen as an ongoing process rather than a single act or policy intervention.

The process of organic placemaking is rooted in community participation and contextual analysis of the social, physical, ecological, cultural, and spiritual dimensions of the particular place [9]. Understanding the placemaking approach from this perspective brings to the fore the tangible and intangible potentials of the space that can enhance its communal assets and eventually create positive impact in various aspects of the urban realm. The place itself also has a spiritual aura that is called the "genius loci," or the spirit of the place [10]. A unique attribute of placemaking through a place-led approach is the integration of the spiritual aspect that is achieved through the deliberate prioritisation of human experiences, feelings, values, intentions, and beliefs in the placemaking process.

Furthermore, another element of placemaking is symbolism [11]. Kellett [12] explains that symbolism as a form of depicting the meaning of a place. It entails the collective and individual experiences of the inhabitants and thus, defines the identity of the community [12]. Streets, public places, and communal centres also become part of symbolism as they manifest place meaning by showcasing the socio-cultural identity of their inhabitants.

Organic placemaking also takes place in informal settlements where local planning authorities offer various degrees of endorsement or condemnation [12]. Kellett [12] explains that the occupants of informal settlements simultaneously conceive, self-build, and occupy the environment, demonstrating creativity and ingenuity with the limited resources available to them. The built environment created as a result of this constant and dynamic organic placemaking has place meaning and incorporates memories of the past life of the rural migrants who have moved to make home in the informal settlements, and thus, depicts their cultural heritage.

\subsection{Sustainability and Placemaking}

Sustainability looks for ways human, human-made, and natural functioning guarantee longevity in existence and use. The organic placemaking process uses local resources, and utilises and enhances unique characteristics of a particular place within the people's capacity to maintain and manage the space and simultaneously thoroughly enjoy community life [13]. Horlings [14] acknowledges the common assumption that place-based approaches can instigate a sustainable development process within communities and regions. This assumption is made based on the manifold common grounds between sustainable development and the placemaking approach as a human-centric ideology and view of the world. Both concepts and associated processes tend to overlap in many respects.

Although sustainability integrates environmental, economic, and social priorities [15], placemaking emphasises the importance of community. However, it is inevitable to also include the biophysical environment, employment opportunities, education, and arts together with all other social aspects in the placemaking process. Within an informal settlement, the organic placemaking process is active and visible through a self-initiated, incrementally created built environment that allows people to generate dynamic utility out of a given space and limited resources. In the informalities, the community-driven process of designing public spaces (streets, sidewalks, plazas, squares, campuses, parks, and so 
on), often in the form of mixed-use development, allows them to host a variety of activities for diverse audiences while remaining well-connected to the larger city or town.

UN-Habitat encourages the placemaking process to instigate sustainability in communities because it [16]:

- Empowers and engages all sections of the community;

- Delivers practical results with visible positive impacts on the community;

- Supports the delivery of basic infrastructure and social services;

- Stimulates economic and cultural activities;

- Improves people's lives.

As Massey [17] (p. 66) stipulates, "what gives a place its specificity is not some longinternalised history but the fact that it is constructed out of a particular constellation of relations, articulated together at a particular locus." Ordinary people find solutions from their memory, past experiences, and ancestral knowledge, and put forward ideas that induce a comfortable lifestyle while preserving their values and norms [18].

\subsection{Urban Informal Settlements and Placemaking}

Migration from rural areas to cities in developing countries often leads to the formation of urban informal settlements [19]. Such rural migrants make their way to cities, leaving behind their tangible physical heritage while carrying along their intangible cultural assets and value systems. Some of their intangible assets and values end up being assimilated into the informal settlements of the urban realm. As Neuwirth [20] (p. 11) states, "massive migration from rural regions to urban centres of the world" is taking place due to multiple factors, such as the mechanisation of agriculture and the promising employment opportunities, services, and amenities offered by cities. He explains that ironically, "once they [rural migrants] got to cities of their dreams, the migrants have become squatters" [20] (p. 11). The term "informal settlement" is defined by theorists and urban planners differently. Informal settlements, prevalent across many countries, are often referred by their local names, such as frevala, katchi abadi, kampung, and hutongs, or described negatively as slums, squatter areas, or shantytowns. However, these settlements are universally seen as areas of social injustice and a manifestation of housing shortage, socio-spatial exclusion from the urban realm, and, most emphatically, as poverty-stricken zones [21] (p. 2). Such descriptions overlook the ability of informal settlements to provide opportunity for the urban poor, largely comprising rural immigrants, to avail of affordable accommodation in the city. Informal settlements serve to fill the gaps in the urban housing supply often caused by inadequate and inefficient urban planning and policy.

Informal settlements can be seen as places of diversity and cultural hubs inhabited by striving, enthusiastic people who have a greater ability to adapt and survive with the bare minimum resources. This alternative dimension of informal settlements was put forward by theorists such as Mangin and Turner [22] (p. 127), who looked at them as "highly successful solutions to the problem of mass urbanisation."

More recently, placemaking has been endorsed by UN-Habitat as a way to support the well-being of local communities in contested places [23]. Informal settlements are prevalent in the Global South, where 90 percent of the world's urban growth is expected to happen in the next 30 years [24]. The Global South is also facing unprecedented challenges requiring urgent responses, including action on climate change; making cities more inclusive, resilient, and sustainable; and the overall quest to implement the Sustainable Development Goals [25]. As in most of the Global South, cities in Pakistan are characterised by numerous informal settlements, i.e., unplanned "places" with poor security of land tenure, dilapidated housing, infrastructure, and sanitation. It is contended that within informal settlements in South Asia, placemaking provides an opportunity to reach out to vulnerable and marginalised communities, serving as a medium of cultural proliferation from regional areas to the city.

Placemaking offers a perspective to bring to the fore the normative, ordinary, and mundane aspects of the community that are, in reality, vital for its existence and identity [26]. 
Furthermore, the knowledge, skills, memories, and experiences that rural migrants bring to cities often contain traces of sustainability values that can, through placemaking, make urban environments more sustainable. Where dwellers of informal settlements can share their rural values with the urban community, their day-to-day lifestyle and built environment shaped through informally generated spaces, homes, and streets would reflect and preserve people's village memories. If these values are not shared or their practice is not acknowledged, they are at risk of extinction. As meanings and values are induced in a place by creating, reproducing, and defending them [27], the dwellers of informal settlements effectively protect and represent their rural cultural heritage in pockets within the urban fabric.

This paper presents a case study of France Colony (in Pakistan, the word "colony" is commonly used to refer to "a residential settlement," perhaps as a legacy of urban planning practices carried out during the British colonial rule that ended in 1947), an informal settlement that sits at the heart of the planned modernist city of Islamabad, Pakistan, whose master plan was envisioned by the Greek urban planner C.A. Doxiadis in 1962 [28]. It investigates the imagery of the informal built environment developed through organic placemaking by rural migrants who have settled in France Colony. This placemaking has never been analysed previously, and by examining life in the informal settlement we aim to understand the contribution of these dwellers to urban life and improved sustainability in the city.

\section{Materials and Methods}

In line with the views of Kara et al. [29], the conceptual positioning of the study incorporates views, beliefs, and values shared by the researchers that then guided the methodological choices. The overall research framework is placemaking, using the case study of France Colony, located within Sector F-7 of Islamabad, Pakistan (see Figure 1).

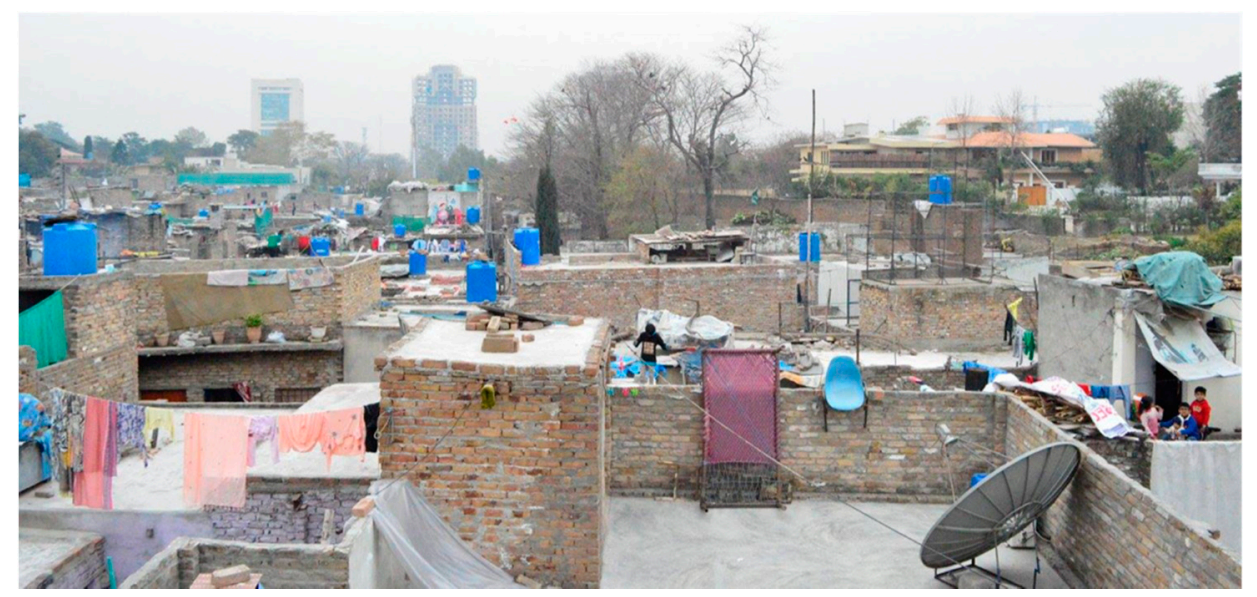

Figure 1. Bird's-eye view of France Colony showing proximity to high-rise commercial buildings (namely, Blue Area) in Islamabad. Source: authors.

As a case study is an established research method in social sciences and humanities [30] and an approach that allows for in-depth exploration of intricate phenomena within their specific settings [31], it was chosen to explore placemaking processes in the informal settlement. The case study approach is particularly suited to exploring and understanding placemaking within the spatio-cultural dimensions of an informal settlement. Within this approach, two main methods were used, namely, transect walks and mapping. The research framework and methods are explained further below.

\subsection{Research Framework: Placemaking}

A basic placemaking format sets the foundation for further refinement and contextualisation of the data collection process during the course of the investigation. The ongoing 
adjustments to data collection sought to ensure that no important social or spatial characteristics were missed during this process. A place-led development strategy developed by Project for Public Spaces (PPS) [16], a non-governmental organisation (NGO), was adopted to understand, explore, and document the place and its characteristics. The PPS strategy for engagement with public spaces is underpinned by the work of urbanists like Jane Jacobs [32] and William Holly Whyte [33] and the cultural anthropologist Margaret Mead [34]. According to PPS [35] (p. 1), "placemaking facilitates creative patterns of use, paying particular attention to the physical, cultural, and social identities that define a place and support its ongoing evolution."

Being developed in the Global North, the PPS placemaking framework (see Figure 2) was contextualised and adapted for application to the places in the Global South, such as the France Colony case study. The biggest adjustment was required in the description of the informal nature of the place, where its location and form become more important than the sociability characteristic in the PPS framework (see Table 1). Two of the other three attributes also needed adjustment (see Table 1) in order to facilitate the description and evaluation of France Colony as an example of an informal settlement.

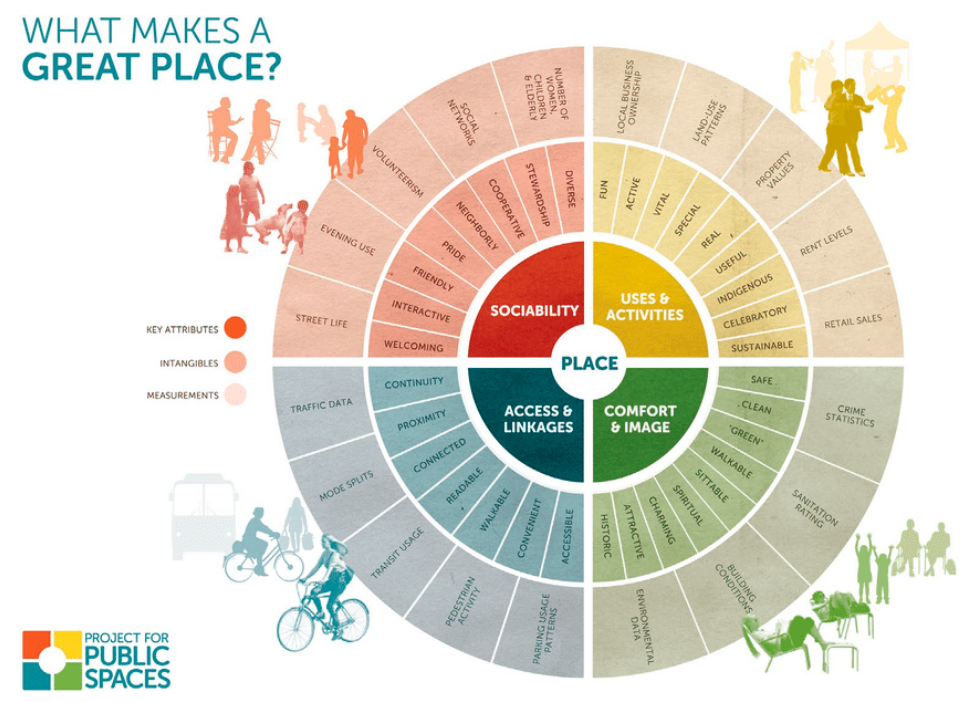

Figure 2. Place diagram developed by PPS. Source: https:/ / www.researchgate.net/figure/Theexisting-Place-Diagram-by-the-PPs-source-PPs-2003b_fig1_314234509, accessed on 17 June 2021 (copyright granted).

Table 1. Attributes of a place.

\begin{tabular}{cc}
\hline Project for Public Places & Urban Informal Settlements \\
\hline Sociability & Form and users \\
\hline Uses and activities & Activities and amenities \\
\hline Comfort and image & Image and characteristics \\
\hline Access and linkages & Access and linkages \\
\hline
\end{tabular}

Source: authors.

The adapted four attributes of the informal settlement were visualised through the following maps:

- Form and user: This map places the informal site within the context of the city and depicts its relationship with the surroundings while documenting the figureground features of the settlement. Figure-ground maps are commonly used in town planning to show the plan-form of buildings in a simplified reductionist way while "omitting most information typically mapped in built-up areas-topography, highway 
infrastructure, administrative boundaries, landscape features < street names" [36] (p. 705);

- Access and linkages: This map defines the access routes, movement patterns, permeability of the settlement, and how the site is linked with other places within and around the settlement;

- Activities and amenities: This map documents the socio-cultural elements reflected in the activities carried out by the dwellers;

- Image and characteristics: This map documents elements of symbolism, genius loci, place meaning, and identity of a place.

Using transect walks and mapping as methods, the four maps were generated to encompass the tangible and intangible sustainability aspects of the life of the inhabitants in the selected informal settlement (see Table 2).

Table 2. Stages of the placemaking methodology.

\begin{tabular}{|c|c|c|c|c|}
\hline Preparation & $\begin{array}{l}\text { Create } \\
\text { figure-ground } \\
\text { plan (Auto-CAD } \\
\text { Software) of } \\
\text { France Colony } \\
\text { by Google } \\
\text { Maps/GIS }\end{array}$ & $\begin{array}{l}\text { Identify and } \\
\text { contact } \\
\text { a "gatekeeper" }\end{array}$ & $\begin{array}{c}\text { Collect } \\
\text { secondary } \\
\text { data on } \\
\text { France Colony }\end{array}$ & $\begin{array}{l}\text { Create a } \\
\text { tentative list of } \\
\text { attributes to be } \\
\text { observed } \\
\text { according to the } \\
\text { PPS model } \\
\text { (Figure 2) }\end{array}$ \\
\hline Transect walk & $\begin{array}{l}\text { Conduct and } \\
\text { record on-site } \\
\text { interviews } \\
\text { and group } \\
\text { discussions with } \\
\text { community } \\
\text { members }\end{array}$ & $\begin{array}{l}\text { Take on-site } \\
\text { photographs }\end{array}$ & \multicolumn{2}{|c|}{$\begin{array}{l}\text { Record observations and data on } \\
\text { four figure-ground maps according } \\
\text { to the four attributes of form and } \\
\text { user, access and linkages, activities } \\
\text { and amenities, and image } \\
\text { and characteristics }\end{array}$} \\
\hline Analysis & \multicolumn{4}{|c|}{$\begin{array}{l}\text { Analyse and synthesise data from all methods under the four attributes of } \\
\text { form and user, access and linkages, activities and amenities, and image } \\
\text { and characteristics }\end{array}$} \\
\hline $\begin{array}{l}\text { Translating } \\
\text { findings onto } \\
\text { maps }\end{array}$ & \multicolumn{4}{|c|}{ Create four maps of the attributes using Abode Photoshop (software) } \\
\hline
\end{tabular}

Source: authors.

\subsection{Research Method: Transect Walk}

A transect walk, a method extensively used in landscape design, was applied as a tool to understand a place in more recent years [37]. Diedrich et al. [38,39] stipulate the transect walk as a method for on-site thinking with informed practices of place appreciation in a unique context while exploring its diversity and characteristics. It is a seen-as method suitable to explore the socio-cultural dimensions of a particular place [40]. The method of the transect walk seeks to investigate the "articulated moments in networks of social relations and understandings" [17] (p. 154) within the informal community.

The transect walk method allows for on-the-spot discussions about a particular place with instant feedback gathered from community experiences [41]. For the case study, different routes were taken for the transect walk on each visit to the site of France Colony for a deeper insight into the nature of the place and its important characteristics. This facilitated discussions with members of the community at a large number of specific locations, providing an informed perspective on daily life routines, needs, local behaviours, and everyday challenges due to space and other constraints. Informed photography was also performed to document and facilitate the deciphering of the meaning of the place. 


\subsection{Research Method: Mapping}

Mapping as a method is simply the process of creating a map. According to Corner [42] (p. 213), mapping is also an exercise that not only measures and describes the world, but also acts as an enabling tool to create and build potential. There is a myriad of different maps that can be created, such as topographical, physical, political, climatic, mental maps, and roadmaps, but of particular interest in placemaking are maps that help understand the socio-cultural landscape of the place. Such cultural mapping is "a process of collecting, recording, analysing, and synthesising information in order to describe the cultural resources, links, and patterns of usage of a given community or group" [43] (p. 8). It helps make culture more visible [44], particularly that of the dwellers in informal communities.

This understanding of mapping was used to produce the four maps for the case study to encompass all socio-cultural aspects of the selected informal settlement. Information gathered during the transect walks was used to prepare and further analyse the informal neighbourhood's spaces. The maps sought to document the movement patterns of people and invisible elements of the place that other visual data collection methods (such as photography) cannot record. Observations gathered on transect walks and on-site discussions were also incorporated and depicted on the maps along with the physical elements. The maps were prepared with the help of a GIS survey, Google Earth, AutoCAD, and Photoshop software and supported by on-site photography.

The map creation was deemed an essential task, as it provided a medium to depict the empirical data of the spatial characteristics of the informal settlement and pinpointed social activities in terms of their spatial configuration. This exercise consolidated the socio-spatial data collected during the transect walk, including site visits, interviewing of informants in the settlement, and photography. It gave a clear understanding of the place, which is documented in this paper.

Care was taken to ensure that elements with a potentially significant positive or negative impact on sustainable liveability of the community were marked on the maps. The consciously created maps aimed to provide adequate and relevant information from a sustainability lens about the organic placemaking in the informal settlements.

\subsection{Ethical Considerations}

As the study involved humans as participants, ethical standards in compliance with Australia's National Health and Medical Research Council (NHMRC) and National Statement on Ethical Conduct in Human Research needed to be followed. A low-risk ethics approval (number-HRE2018-0272) was granted by the Curtin University Human Research Ethics Committee before commencement of the fieldwork. Consent, privacy, and confidentiality of all field investigation participants were ensured at all times.

\section{Results}

In this section, we first introduce France Colony and then describe the four maps created. This helps understand the placemaking phenomenon spatially and analyse its socio-cultural landscape from a sustainability perspective.

\subsection{Introduction to France Colony}

France Colony (also referred to as French Colony) is an informal settlement in Islamabad, situated in the heart of the rich cultural region of Pakistan's capital city. Islamabad has an active regulatory authority, namely, the Capital Development Authority (CDA), which monitors illegal construction and encroachment in different areas of the city. However, France Colony is an established area of the city with no immediate plans for removal or clearing. The informal settlement took its name from the French embassy that used to occupy this area [45].

With around 8000 inhabitants, France Colony is a metro-core informal settlement, which means it is situated in the midst of the urban centre of Islamabad [46] and surrounded by upper-class areas. It is mostly inhabited by Christian labourers, who, either themselves 
or their parents, took part in the construction of the largest public hospital of Islamabad, the Pakistan Institute of Medical Sciences (PIMS), in the 1980s. The community has a church as well as mosques with hardly any disagreements based on faith [47].

Located on the banks of the Kanitawali Kas, a stream that feeds into the Nallah Lai (a major water stream), the settlement cropped up over time on the marginal land left as incidental open space, according to Islamabad's master plan. The Naalah, a stormwater catchment area, is a vulnerable place that is inundated yearly by seasonal flooding due to the heavy rainfall during the monsoon season [48].

\subsection{Form and Users}

The Form and Users map in Figure 3 depicts France Colony in the midst of Islamabad's commercial activity zone, namely, Jinnah Super Market, and sharing borders with the highincome residential areas in Sector F-7. Being nestled in a formal residential area from three sides is the reason for the inhabitants of France Colony being predominantly employed as domestic workers in the richer neighbourhoods in close proximity. Some work as employees in the nearby government departments [49].

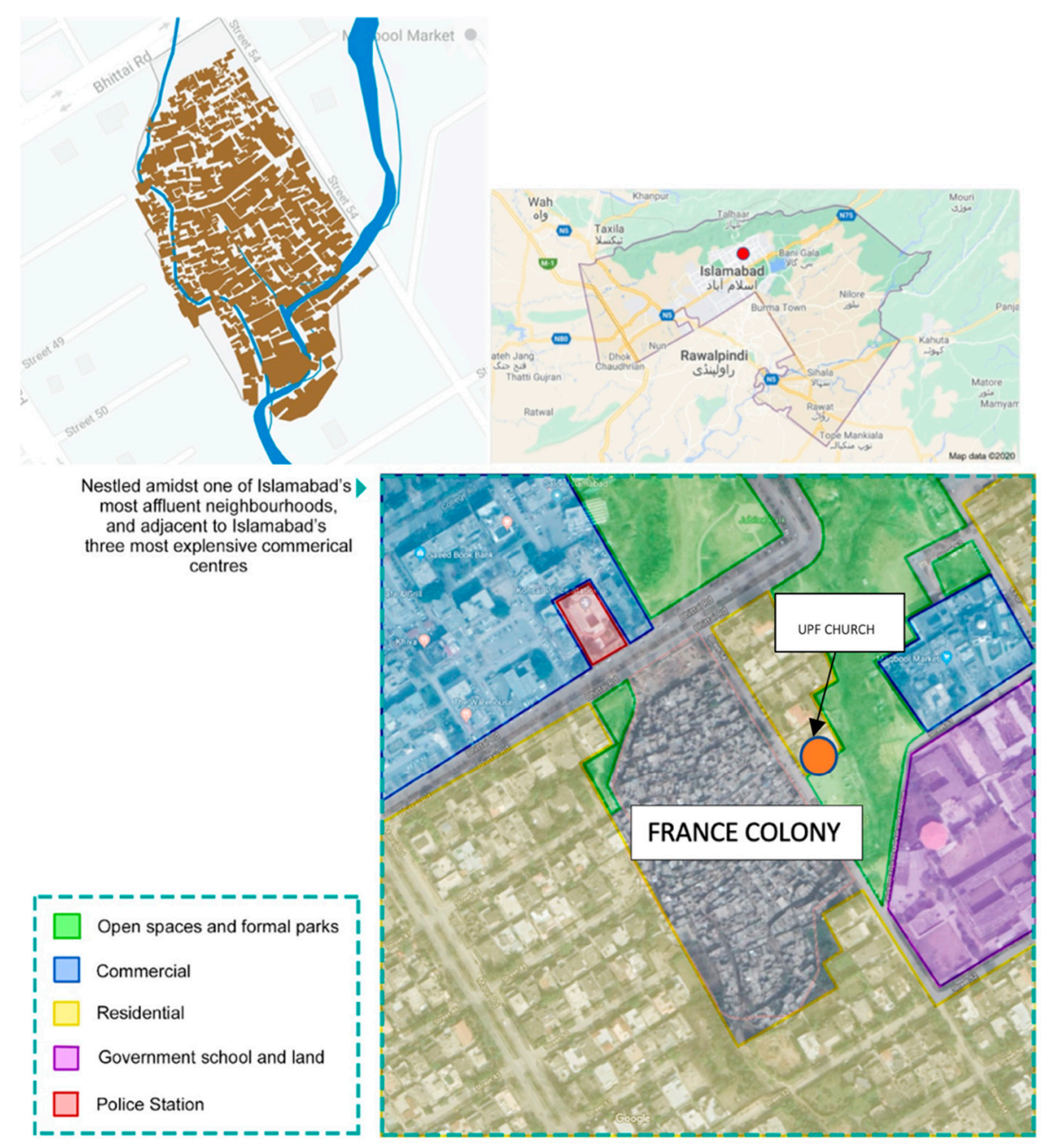

Figure 3. Form and Users map (France Colony). Source: authors.

Two aspects of the location and form of France Colony are of particular interest from a sustainability perspective. The first relates to densification of the informal settlement and the other to dealing with the waste it generates. 


\subsubsection{Compactness and High Density}

The high density of the settlements and their encapsulated form also manifest as examples of the typical metro-core slum of Pakistan [46]. Figure 4 shows the densification of the community area with time and the constant influx of migrants and population increase. Such densification moulds the urban morphology, streetscape, and living conditions of the inhabitants. Densification has mostly happened by construction in the open areas (sehan) in houses, by sub-division of plots, and also by adding another storey to houses incrementally to accommodate expanding families when the children of the initial migrants marry. Therefore, in the absence of by-laws and building regulations enforced by CDA, the informal dwellers have modified the place according to their changing requirements over time and on whims.

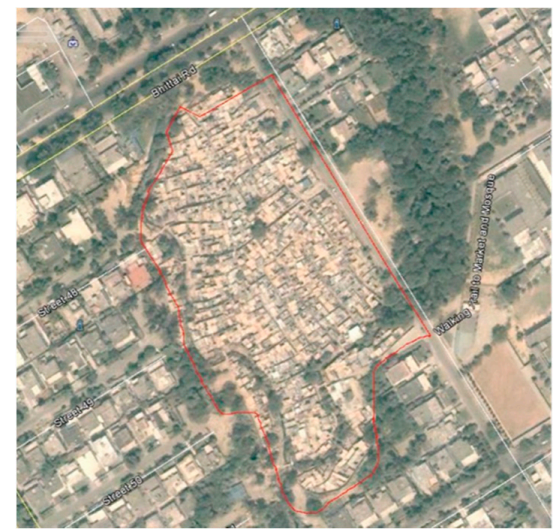

(a)

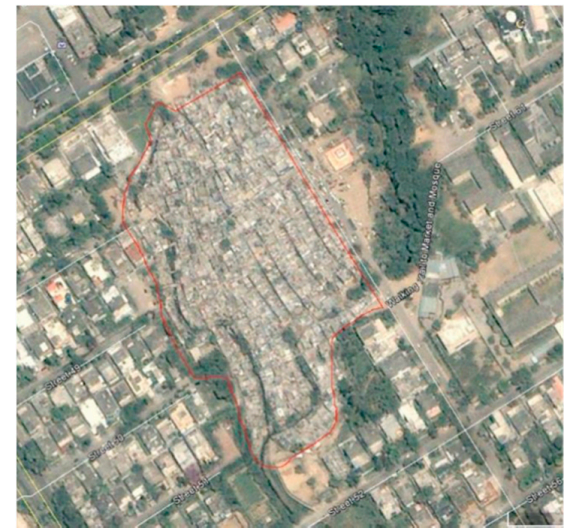

(b)

Figure 4. Densification of France Colony over time. Source: (a) Google image 2004; (b) Google image 2017.

This densification of the settlement is an example of maximum utilisation of land resources in a compact manner. In contemporary sustainable development discourse, such an urban design approach is described as the "compact city" [50]. An OECD Report [51] also outlines the importance of compact city policies to achieve green growth with a smaller environmental footprint, better economic efficiencies, and job opportunities, as well as social benefits of shorter travel distances and local availability of services. The inhabitants of France Colony have modified the place according to their changing requirements and adapted accordingly to the incrementally ever-changing built environment around them. By doing so, they have generated a lot of growth efficiencies.

\subsubsection{Environmental Hazard and Pollution of the Naalah}

France Colony was settled on vulnerable marginalised land on the banks of the Naalah. Islamabad is a city situated in the foothills of the Margallah Hills and is supplied with multiple seasonal water streams that flow during the monsoon season or heavy rainfall days. However, such settlements have altered the natural drainage system of rainwater runoff and informalities such as France Colony are using those streams as landfill sites, dumping waste, clogging them, and creating environmental hazards for the community.

During the transect walks, a recycling yard (see Figure 5) was seen to be located in the settlement, which indicates that the inhabitants are trying to re-use waste. They are not oblivious to the concept of recycling in lieu. A local explained that pollution, though a physical issue, is conveniently resolved in the villages (from where most inhabitants have migrated to France Colony) by disposing biodegradable material and recycling any nonbiodegradables. However, the same people who have efficiently carried out this practice in the villages appear indifferent and reluctant to continue it, blaming the problems on the system and the state. Whereas in the villages they were doing waste management on 
a self-help basis, the main reason for the poor recycling, according to the local, is lack of leadership and poor communal ties.

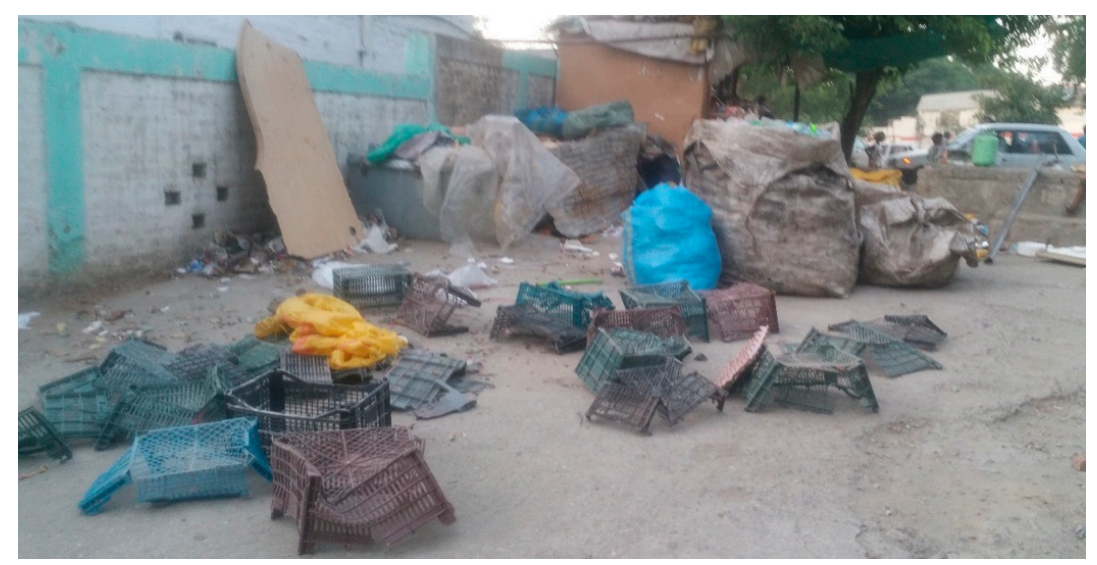

Figure 5. Patras Kabaria junk/recycling yard in France Colony (marked on map 2). Source: authors.

The inhabitants of France Colony have cultural values that align with a sustainable mindset, but constraints related to governance, ownership, and management have made them shun their old practices and gel into the urban system where they believe the state must provide all amenities, including waste management. These people have the potential for self-management and self-governance but lack direction once they leave their traditional way of living in the pursuit of adapting to an urban lifestyle that is doing harm to them and the natural environment.

Local initiatives are small-scale and not enough to cater to the amount and nature of waste generated in France Colony. The "accidental sustainopreneurs" make a living while assisting the informal settlement and overall making society more sustainable [52].

\subsubsection{Spiritual Hub}

Spirituality is intertwined with sustainability from a philosophical and practical perspective because it is what makes people care about future generations, other species, and nature. In the quest for happiness and balance in their lives, people often resort to religion.

There are eight churches in total that serve as important landmark [53] buildings with cross symbols visible from different areas of the settlement. The United Prayer Fellowship (UPF) Church located on the other side of Street 54 welcomes worshippers from France Colony, although it is not located within the apparent borders of the informal settlement. It claims to be part of the informal settlement through its activity and purpose, as the formal neighbourhoods are Muslim-majority areas. The UPF Church (see Figure 6) is significant as it also attracts the Christian population from other informal communities in Islamabad and serves as a social net within the city. This adds up to the social capital of the settlement and makes it more resilient in times of adversity. The Father of the UPF Church is highly revered by the Christian community in Islamabad.

Many residents serve as volunteers at the church and consequently earn respect in the settlement. A single mom proudly stated that she had been volunteering at the church for 10 years: "I work as a cook in a nearby [formal] neighbourhood and after work come to church for "Khidmat" [volunteering to serve the community for religious reasons]. Daily I come back home at 10 p.m. but I am very content. Everyone in the settlement calls me Sister Shabana and respects me though I live here alone with my kids."

Characteristics of volunteerism and self-help are stirred by the church community. Bashirah explained that all activities of festivity and grieving take place at church. She said, "At the church we organise funerals and festivals, we erect Tamboo [traditional cloth tent] in the open space in front of UPF church. Similarly, wedding functions are 
also done here." The church plays an important role and serves as an area of communal activities during times of festivities and grief; thus, it is a place that unites the settlement's inhabitants and has great potential for leadership, management, and governance roles for the betterment of France Colony. Representing a hub of religious activities, France Colony also offers opportunities for self-reflection and spiritual growth that transcend the quest for sustainability [54].

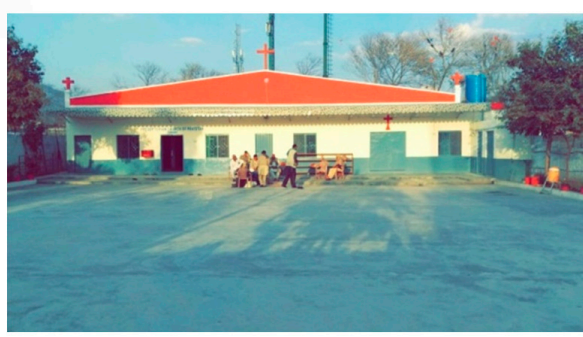

(a)

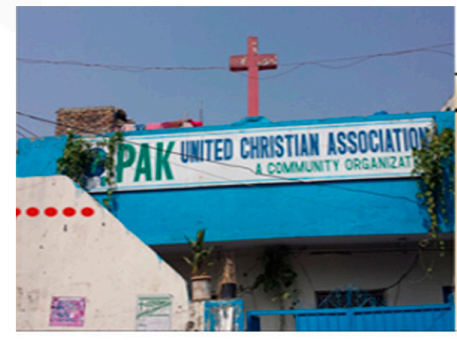

(b)

Figure 6. Churches in France Colony: (a) UPF Church; (b) Pak Church. Source: authors.

\subsection{Access and Linkages}

The movement and connectivity in the neighbourhood is translated into the Access and Linkages map (see Figure 7). It gives a bird's-eye view of France Colony's street web, street hierarchy, adjacent formal roads, and the Naalah (water channel) that dissect the settlement. The map depicts a high-density neighbourhood with a narrow street network and a high built-area-to-open-space ratio. The streets, alleys, and bridges serve not only as connecting mediums, but also as a major place-defining element of the settlement where social interactions take place.

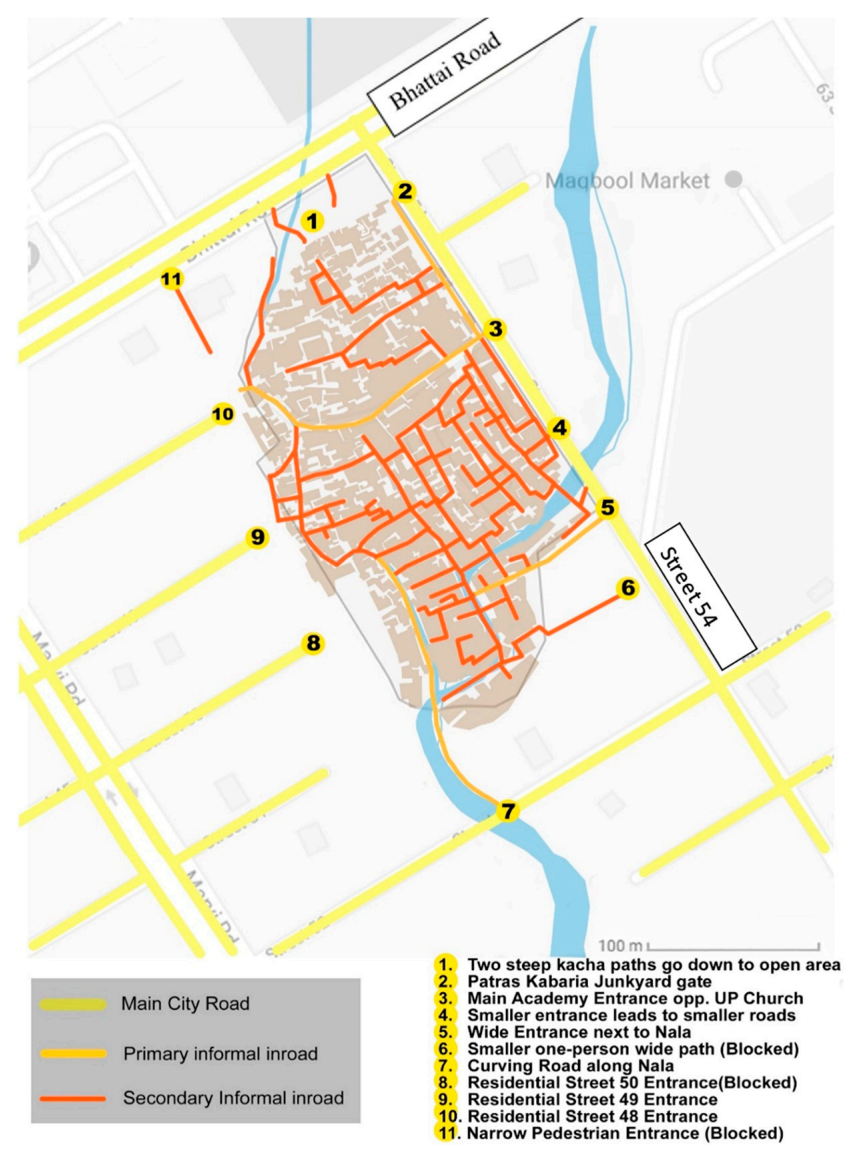

Figure 7. Access and Linkages map (France Colony). Source: authors. 
There is a three-tiered road network within and around France Colony (see Figure 7). The road marked "Main City Road" is part of the formal network around the settlement as per Islamabad's master plan, whereas "primary informal inroads" and "secondary informal inroads" are organically created, self-constructed, and maintained by the inhabitants of France Colony. Main roads with two-way traffic exist only outside the informal settlement. Only three narrow single vehicular roads enter the settlement at points 3, 5, and 7 (see Figure 7). Vehicular access to the site is from Streets 54 and 52 and pedestrian access is from Bhattai Road. The site is encapsulated in a triangular pocket of land with the Naalah and Street 54 forming its edges. Street 54 serves as a spill-over space in France Colony due to the church building flanking the other side of the street, confined by the Naalah and vegetation. One can frequently see France Colony residents playing footfall in this area. The formal road, Street 54, gives the visual impression of being part of the informal settlement.

The whole settlement is connected by a road on the edge of the Naalah that runs on its periphery. Some of the houses are linked through bridges built over the Naalah and others are branched out from that access route. The street network inside the settlement has a very organic layout and either runs parallel or tangent to the Naalah (see Figure 7).

Two sustainability-related aspects of the Access and Linkages map are the functioning of the streets as dynamic spaces of social and economic activities and the sustainable modes of transportation used by the dwellers. They are analysed below.

\subsubsection{Streets as Dynamic Spaces}

There is visible vibrant street life in France Colony. The streets are multipurpose avenues of social interaction, economic activities, playing for children, and many other activities that take place in this space-just like the woman who carefreely cooks her meal on the street (see Figure 8) or like the woman who is relaxing on a charpai (traditional lounge furniture) (see Figure 8). It was observed that streets are semi-private spaces for many people living in the informal settlement. The anatomy of home and streets explained by Blunt and Dowling [55] (p. 2) is applicable here, where streets are seen as "a porous, open intersection of social relations and emotions ... neither private nor public but both."

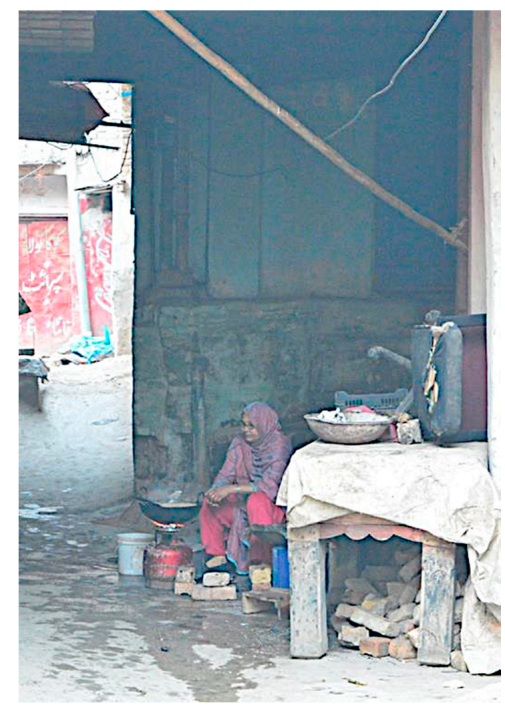

(a)

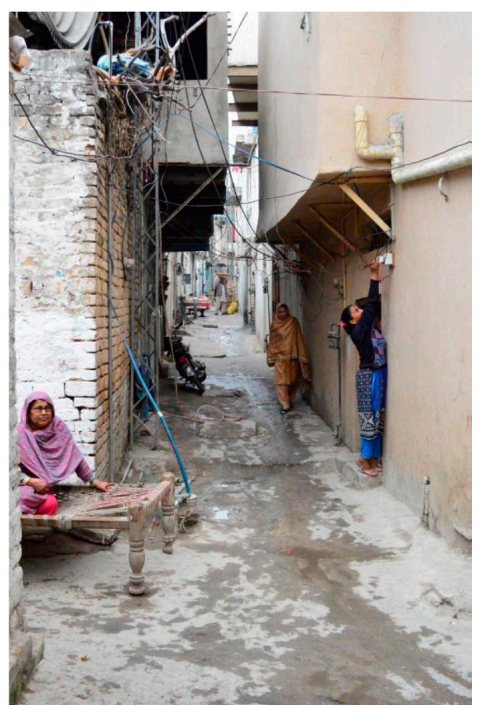

(b)

Figure 8. (a) Cooking in the street; (b) Relaxing in the street on a charpai. Source: Authors.

The streets of France Colony have multiple uses in addition to accessibility and serve as elements of social sustainability within the settlement. They are places of social interaction, gossip, displays of emotions and expressions, places of leisure or relaxation, and also places of micro-economic activities. They serve multiple purposes to cater to the social and cultural needs of the dwellers within the confined space and are used by people of 
all age groups and genders. Upon asking questions from the locals about places of play for children during the transect walk, many said streets serve as playgrounds, too. It was uncanny to see the transformation of the streets as per the versatile uses of these alleys. By escaping the automobile dominance present in city life in formal settlements across the world, the streets remain vital to the well-being of urban dwellers [56].

\subsubsection{Sustainable Modes of Transportation}

All secondary informal streets are narrow and the area is inaccessible to automobiles. However, bicycles and motorbikes were seen on these streets during the transect walks. Most streets are about 1.5-2 m wide. Therefore, accidently or unintentionally, the inhabitants of France Colony adopt sustainable modes of transportation, such as walking or cycling within the settlement.

The streets, especially the secondary informal roads (see Figure 9), can be used for manifold activities due to the absence of cars and larger vehicles. These alleys can only cater to motorbikes and bicycles, which makes them an interactive environment, unlike formal streets where automobiles dominate the streets and thus restrict social interaction. They offer a dynamic interplay of infrastructure and humans in a reciprocal sustainable relationship [56].

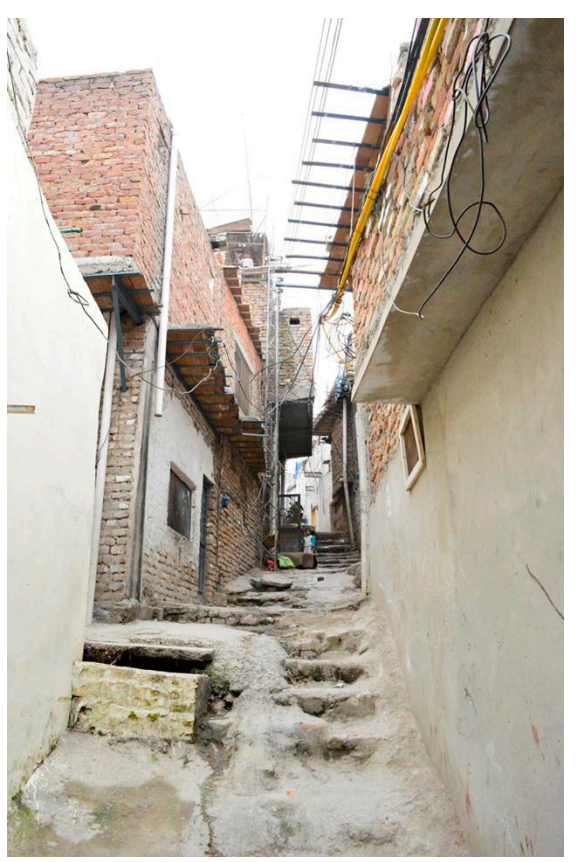

(a)

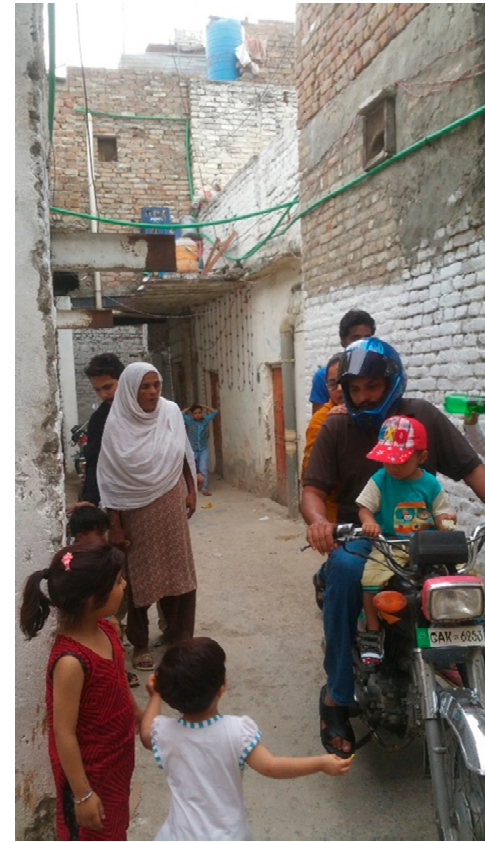

(b)

Figure 9. (a) Cantilever consequently creating a comfortable environment for pedestrians; (b) interactive street environment as a semi-private space. Source: authors.

\subsection{Activities and Amenities}

Places are defined by the activities that are carried out in them. Giddens [57] (p. 367) stipulates the significance of activities as "the daily paths of individuals within a given range of locale." He further explains the importance of activities in defining a sense of place that provides a psychological connection between an individual and "the locales that are the settings of the time-space paths through which that individual moves" [57] (p. 367). According to Steadman [58] (p. 3), cultural values are reflected in the spatial configuration of activities taking place in a community, with "culture being overlaid onto the practical functions of life, transforming them and giving them meaning."

The socio-economic and cultural mapping of France Colony manifests it as a selfreliant island with all basic amenities and professional expertise available within the small area. Figure 10 shows the Activities and Amenities map, which indicates a buzzing 
landscape of places of action, including open areas appropriated by the resident dwellers as informal communal spaces.

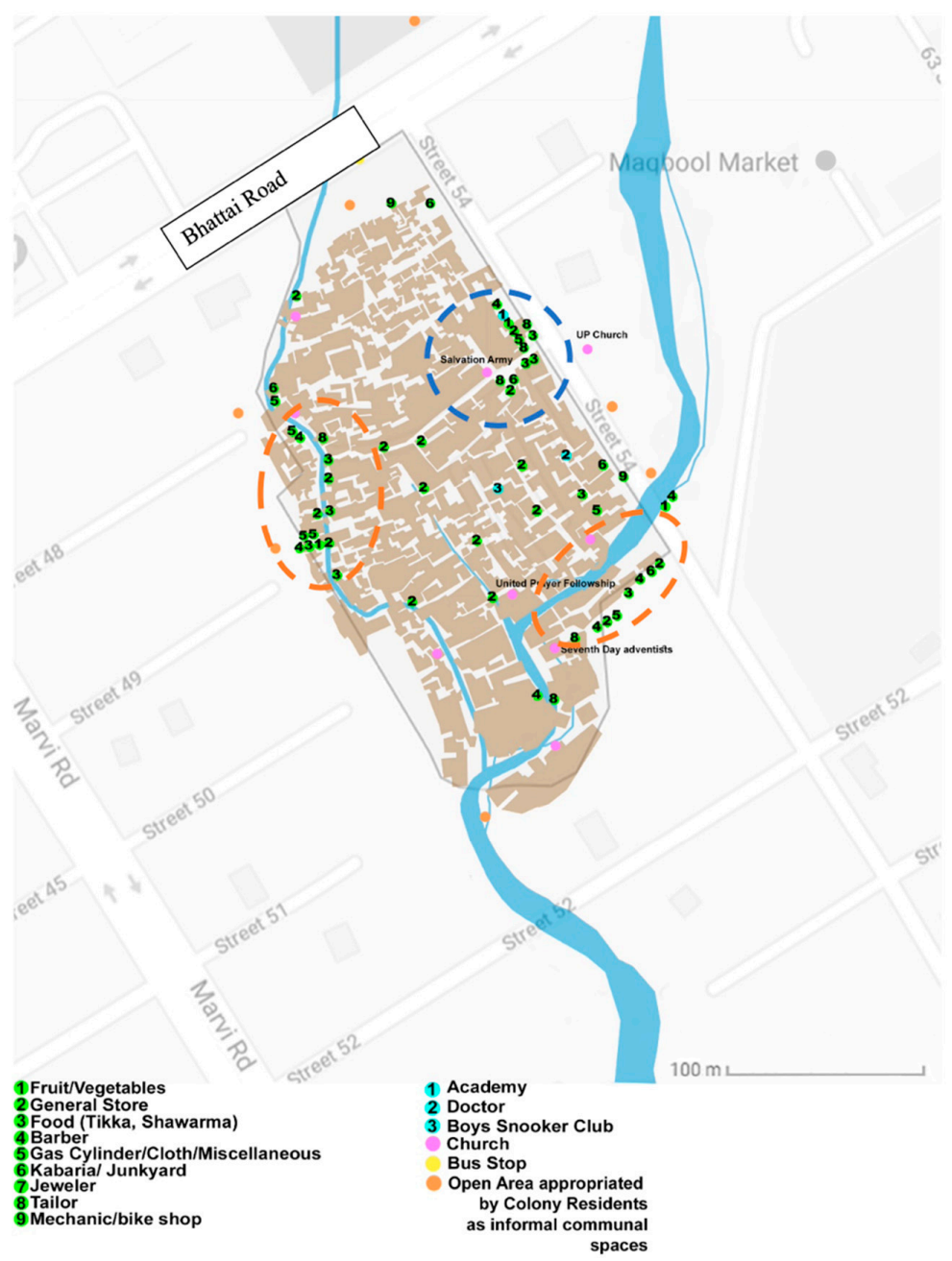

Figure 10. Activities and Amenities map (France Colony). Source: authors.

Four aspects are particularly relevant in relation to sustainability, namely, self-reliance, mixed-use, flexibility/adaptiveness, and spirituality. They describe France Colony as a micro world of social cohesion and resilience.

\subsubsection{Self-Reliant Island}

Ranging from a medical clinic to a school and from a bazaar (traditional marketplace marked as blue and orange dotted circles on the map in Figure 10) to small-scale cottage industry, even the shops are of various typology, such as a beauty parlour, fruit seller, car mechanic, tailor, jeweller, barber, etc. France Colony has it all (see Figure 11). This variety manifests that the needs of the dwellers are met within the settlement and according to their financial means. As the surrounding area is a high-end shopping market of Sector F-7, these people have created their own island of activities. For instance, the tailor in France Colony charges approximately AUD 5 per dress in comparison to the approximately AUD 30 charged in the formal commercial market across Bhattai Road. This observation shows a significant socio-economic divide between the informal settlement and its formal surroundings. During the transect walk, the locals explained that they are only dependant on their surrounding neighbourhoods for employment, transport, and hospital. Besides that, the settlement is self-sustaining in terms of basic amenities and day-to-day living. Although clinics were sighted in the settlements (marked as "doctor" on the map in Figure 10), many inhabitants reported that they migrated from the villages to gain access to 
medical facilities such as hospitals. In reality, they use much more often the medical clinics within the informal settlement.
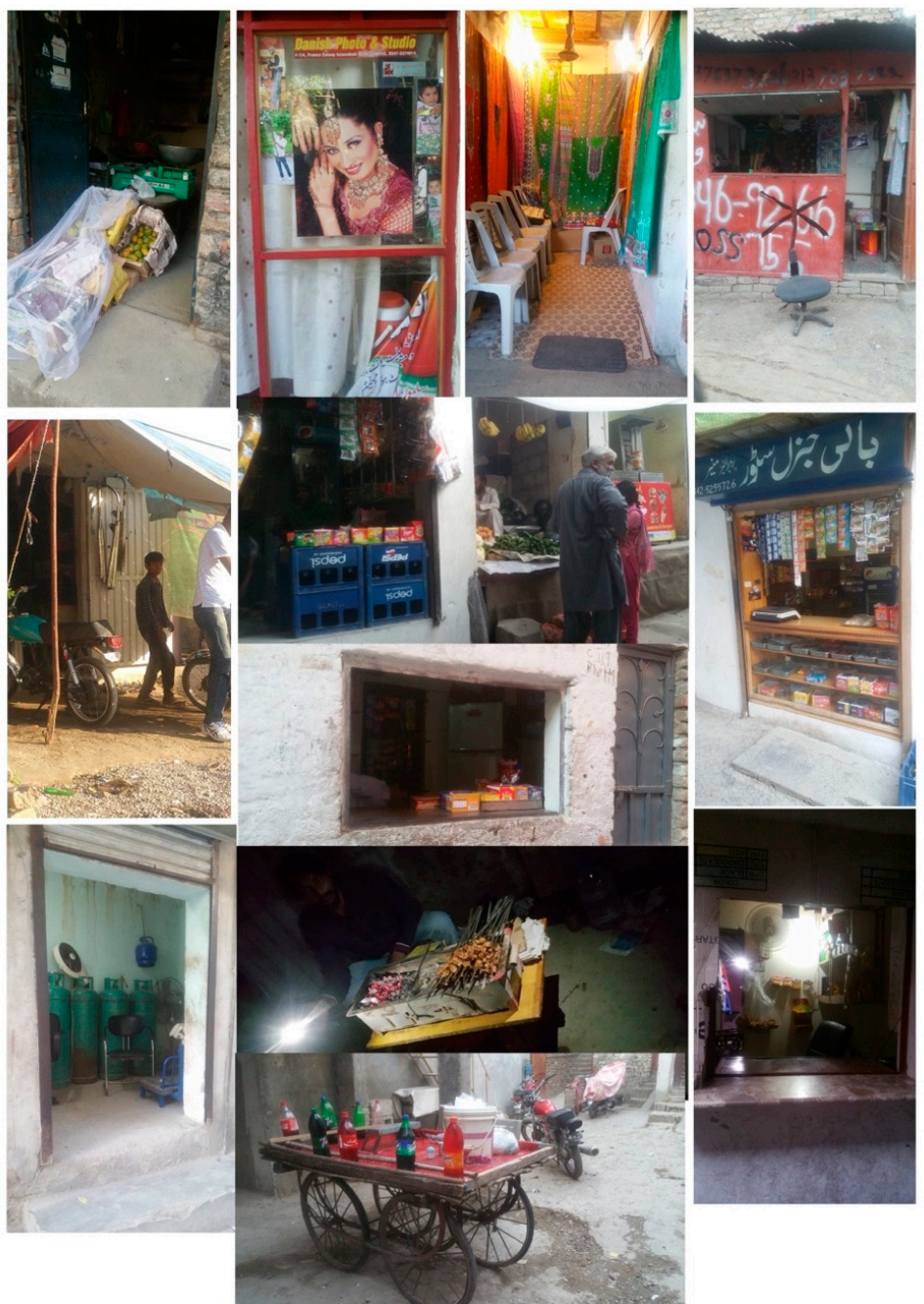

Figure 11. Diverse commercial and leisure activities in France Colony. Source: authors.

With the surrounding areas being high-end retail and markets, these dwellers have created an economic zone that is compatible with their income and accordingly has all the required amenities. They have become economically self-reliant. In fact, the informal settlement has evolved to serve the people and build their resilience through self-reliancean aspiration for any sustainable urban environment [59].

\subsubsection{Mixed-Use Building Configuration and Micro Economy}

Another aspect of France Colony is the scattered pattern of micro-economies across the informal settlement. This shows the mixed-use organic design of the housing, which is an emphatic element of compact city urban planning in a sustainable urban feature [50], as it reduces travel time and urban sprawl and thus, consequently decreases the carbon footprint. Most of the dwellers have used the front room of their house as a shop accessed through the window of the house that opens up on the street (see Figures 11 and 12). The shops' configuration and placement depict informal features; they are run from home and in a relaxed way. Located in different parts of the informal settlement, these shops are accessed preferably through the primary informal roads. Economic density is one of the sustainable features identified in a review of compact city studies across the globe [60]. It is present in France Colony, defines its nature, and facilitates its functioning. 


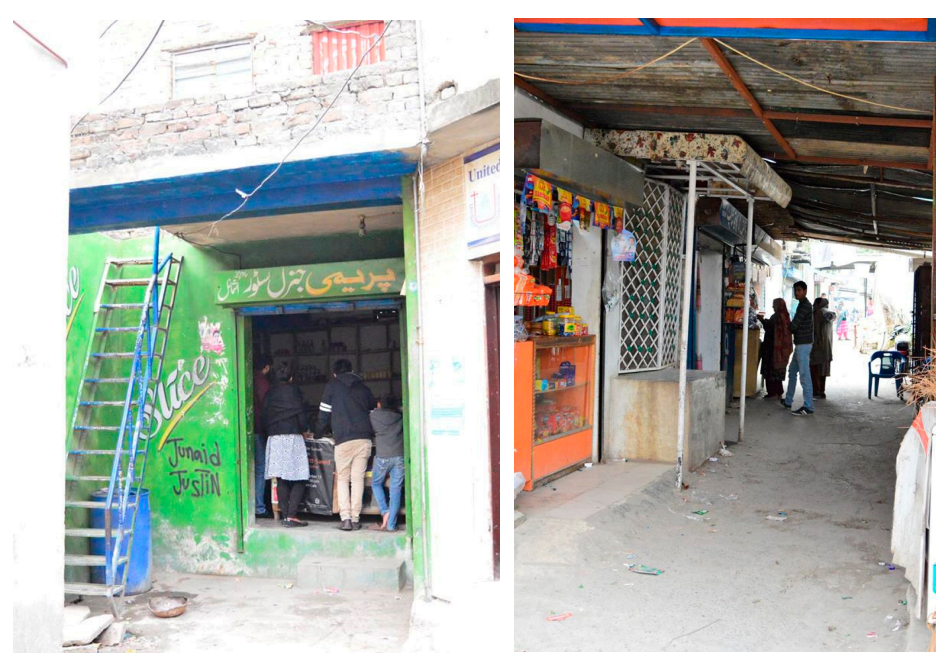

Figure 12. Houses incrementally transformed into shops. Source: authors.

The flexibility of architecture and streetscape has also played an important role in modifying the public places across the settlement. With the absence of by-laws, a malleable built environment has enabled the inhabitants of the settlement to create shops in the front section of the house by using its frontage as a commercial interface to earn a livelihood (see Figure 12). One can witness several entrepreneurship ventures in the area that have become feasible because of the incremental modification of houses and flexibility of the built environment [61]. This virtue of place is not evident in the formal urban environment and is a great asset in creating placemaking opportunities to promote traditional livelihood activities such as arts and crafts with the aid of the entrepreneurship-driven economy of France Colony and creating opportunities for sustainable livelihood. The home and its environment are considered a transactional whole [62] that allows for a range of economic, social, and cultural activities to take place, facilitated by traditional self-built housing, vibrant streets, and mixed use of the land [63].

\subsubsection{Flexible and Adaptable Public Places}

Bazaars and churches are important public places in France Colony. However, for functions and other gatherings, open spaces (marked as orange dots on the map in Figure 10) outside the congested settlement are used. In a daily routine, these areas are used by women to socially interact and by children to play but during evenings mostly male members of the community use the open spaces (see Figure 13).

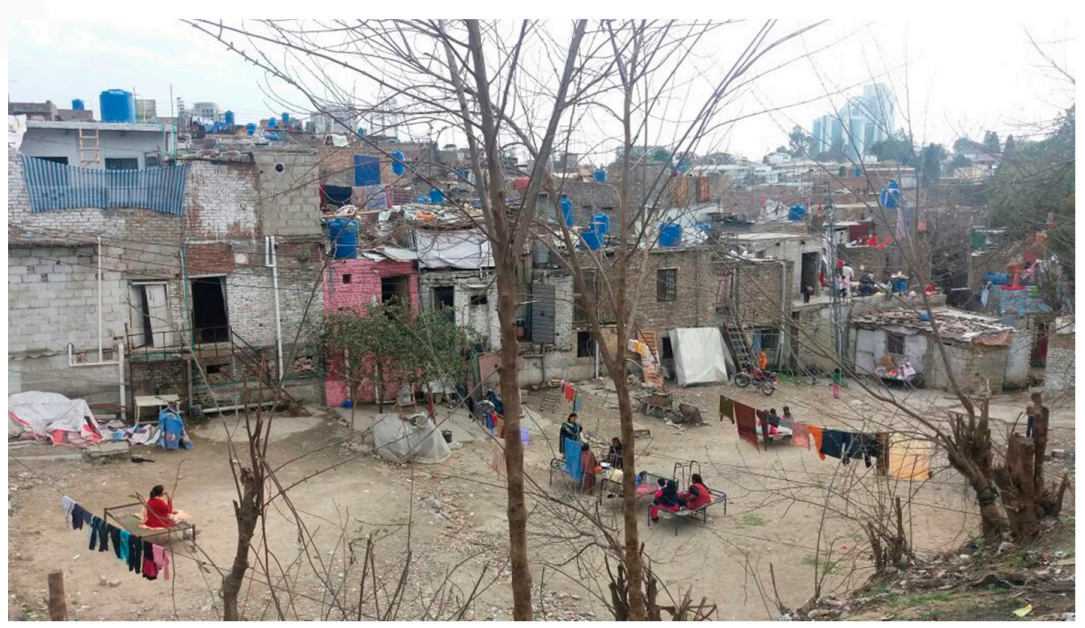

Figure 13. Open area serves as setback from Bhattai Road. Source: authors. 
Thus, each place has multiple uses and users at different times of the day and during different occasions. This virtue shows the flexibility of the informal spatial setting that has enhanced the sustainable characteristics of the place by being flexible and adaptable to different activities at various times of the day. Such flexible public spaces also contribute to the resilience of the informal settlement, as they are readily available in case of extraordinary events, such as emergencies, and can easily be transformed for unexpected uses [64].

\subsection{Image and Characteristics}

France Colony's spatial configuration in terms of image and characteristics is explored to understand the sustainable attributes entailed in the culture of the inhabitants, which is translated into the spatial setting of the informal settlement. They mark elements on a map that define the informal settlement's identity and distinguish it from the rest of the city. The Image and Characteristics map (see Figure 14) also aims to document characteristics of "place meaning," which is the "subjective and emotional attachment people have to place" [1] (p. 7). Therefore, the map documents spatial elements that entail significance of place meaning and identity. This includes significant public places and communal gathering areas that exhibit the sociology and culture of the community. The typology of shops, adornment of houses built incrementally, and other socio-economic activities manifest the character of the place and the culture of its dwellers.

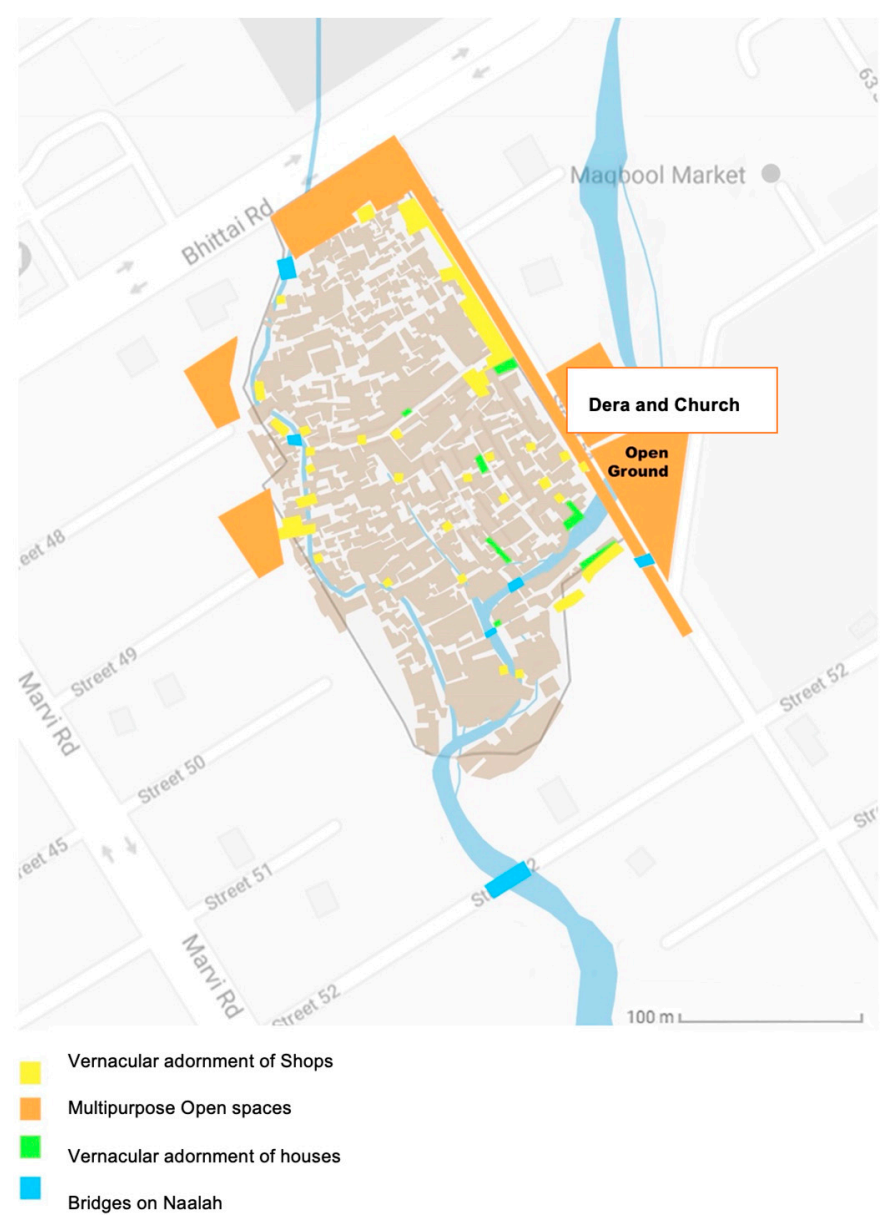

Figure 14. Image and Characteristics map (France Colony). Source: authors.

\subsubsection{Incremental Architecture and Recycled Materials}

In France Colony, the streetscape and houses built incrementally give hints of vernacular architecture and indigenous ways of living. A typical house has private open courtyards at the front and two bedrooms at the back. Most houses have a washbasin in the courtyard 
to indicate concerns about cleanliness before entering the bedrooms and kitchen area. This layout is a compact form of a typical rural dwelling, where most of the activities take place out in the sun for maximum utilisation of daylight and to take advantage of the naturally ventilated space, whereas rooms are only used for sleeping purposes.

Arshad explained that the majority of houses in France Colony, including his, are constructed from recycled bricks and are built incrementally as the family expands. This practice of incremental architecture had modified the density of the built area in the settlement over the years, along with the influx of migrants [65]. The present study examines the existing spatial setting of France Colony; however, historically modified patterns in the built environment and architecture of the settlement over a period of time, depending on the influx of rural migrants, can be investigated in further research.

Indigenous patterns and the use of bright colours are also a reminiscence of vernacular architecture (see Figure 15). Colourful homes and buildings intermittently sprout up unexpectedly in narrow streets sporadically and not very frequently. Salman [66] explains that vernacular architecture has evolved over time and contains many sustainability elements. It uses local materials and technologies originating from the ambient social and natural environment. Such incremental architecture creates local identity, and contributes to placemaking and the sense of place emerging. Likewise, the bridges connecting the settlement across the Naalah (marked in Figure 14) are also a unique architectural characteristic of France Colony.
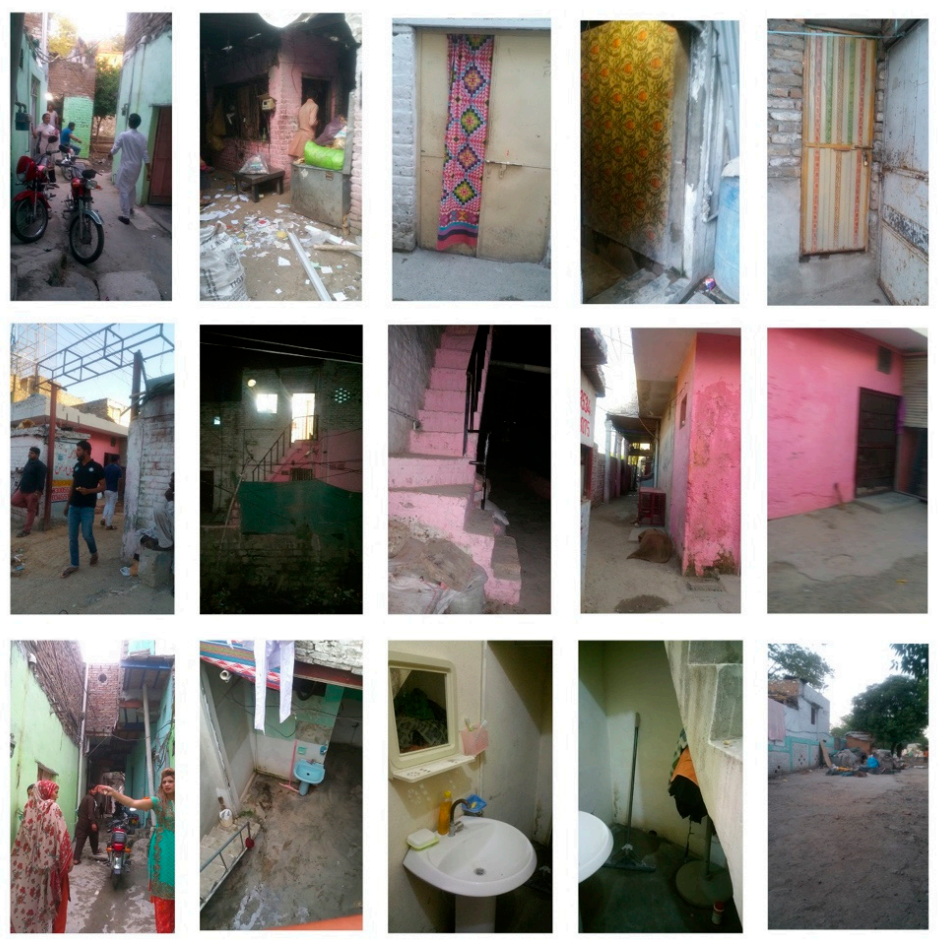

Figure 15. House programming and traditional adornment of buildings. Source: authors.

\subsubsection{Diverse Users}

Bazaars and churches are important public places in the informal settlement. The open spaces marked as orange areas on the map in Figure 14 outside the congested settlement are used by women, men, and children.

Special street furniture in community areas, such as Dera (see Figure 16), is also part of the amenities in these public spaces. The diversity of uses is reinforced by the presence of flora and fauna incorporated as part of the environment by utilising the rooftops as birdcages and for keeping chickens. 


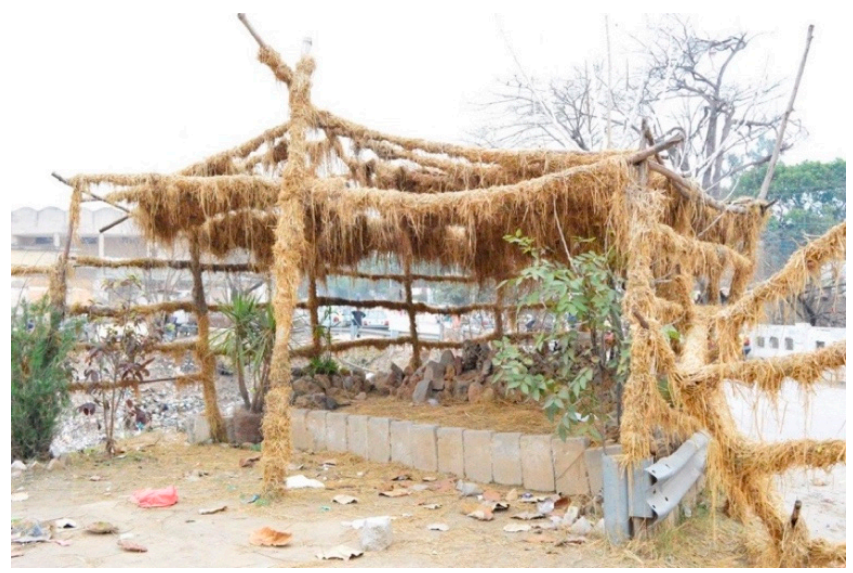

Figure 16. Dera in France Colony. Source: authors.

Domestic animals such as goats, hens, and other birds roam freely in the streets alongside children playing together (see Figure 17). This gives a rural image of coexistence of people and animals. Besides this, adults playing cards and marbles, and children participating in traditional games such as "baraf-pani, pakran pakrai", also give evidence of how these communities contribute to keeping the folk culture alive in the era of technology and social media. These games are important in terms of identity and are sustainable and healthy; however, they easily become extinct in the formal urban culture where technology and globalisation deviate children from traditional games [67].

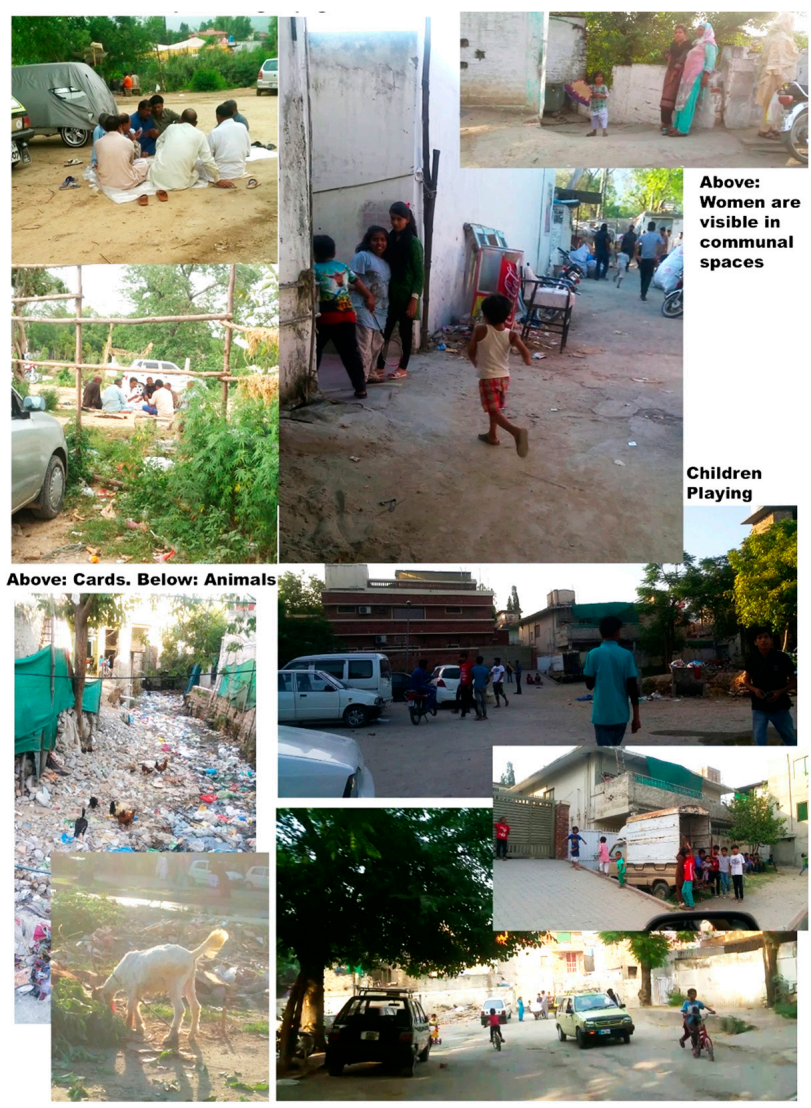

Figure 17. Diverse users of public places. Source: authors.

Kosar said, "here in [France] Colony, there are a lot of people who are trying to keep their rural heritage alive and have not changed their lifestyle." Traditional decorations in 
times of festivity, such as weddings (see Figure 18), show an image of simple yet vibrant indigenous celebrations.

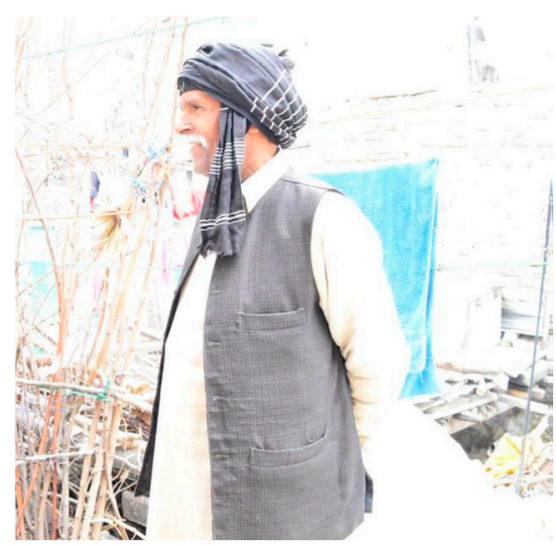

(a)

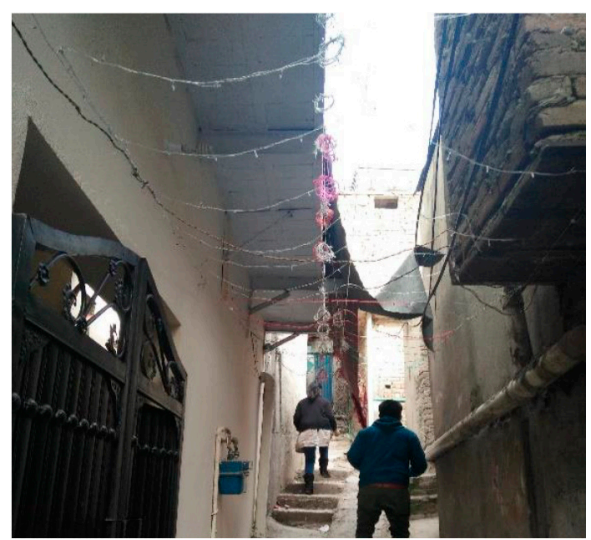

(b)

Figure 18. (a) Traditional attire worn by a local; (b) wedding decorations in the street. Source: authors.

Christmas murals on the walls along the streets, community buildings, and churches (see Figure 19) are a religious expression of the locals as well as a manifestation of their artistic skills, memories, and fantasies. Religious symbols are very popular, especially during the time of Christmas. Installations such as "Charni" (the local name for a Christmas crib decoration celebrating the birth of Jesus Christ), are created by children, explained Emanuel, while enthusiastically describing how the neighbourhood transforms around Christmastime. Such a collective expression of art and culture is an indication of social cohesion and sustainability, where the community makes the effort to keep its rituals, heritage, and values alive by actively practicing them [68].

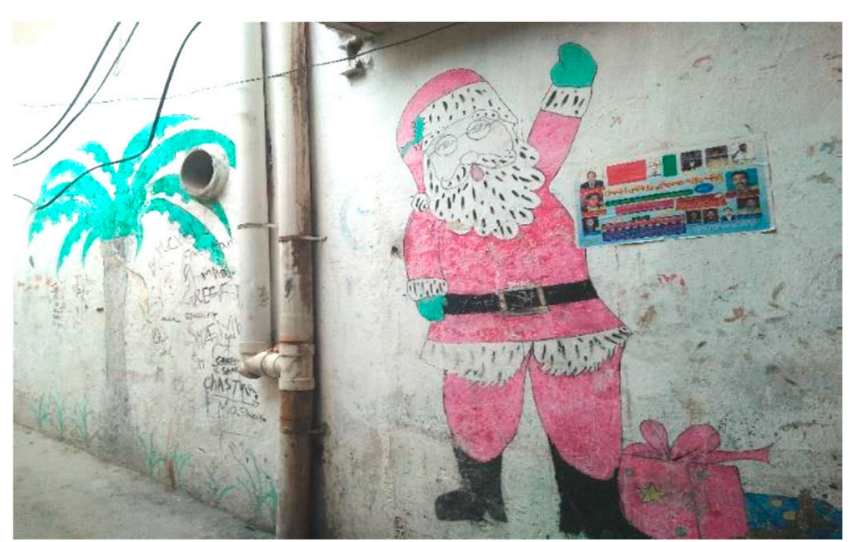

(a)

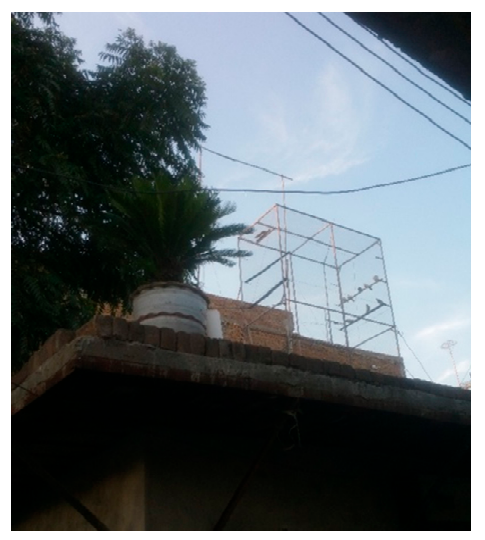

(b)

Figure 19. (a) Mural on the external wall of a church in French Colony depicting Santa Claus; (b) birdcage and pots of plants on the rooftop. Source: authors.

\section{Discussion}

This study documented and analysed the spatio-cultural assets of the informal settlement France Colony from a placemaking approach. This brings to the fore a range of significant sustainability concepts present and practiced by the community either intentionally or accidentally. Sustainability attributes reflected in the cultural values of the rural migrants in the informal settlement transcend the modern world as a paradigm shift from conventional urban planning and development to organic placemaking. They are in fact 
deeply embedded in the cultural heritage of the region and are being practiced in the informal settlements of the cities without being acknowledged, documented, or explored.

Table 3 summarises the findings from the case study organised under the three pillars of sustainability, namely, environmental, economic, and social. Obviously, it is arbitrary where we located a particular finding, as sustainability is about integrating these three pillars, and you can find simultaneous aspects in each of them.

Table 3. Findings from France Colony according to the three pillars of sustainability.

\begin{tabular}{|c|c|c|}
\hline Environmental & Economic & Social \\
\hline $\begin{array}{l}\text { Practicing vernacular } \\
\text { architecture }\end{array}$ & $\begin{array}{l}\text { Practicing micro-economy } \\
\text { and entrepreneurship }\end{array}$ & $\begin{array}{l}\text { Reserves of cultural display } \\
\text { and indigenous lifestyle }\end{array}$ \\
\hline $\begin{array}{l}\text { Use of local and recycled } \\
\text { materials }\end{array}$ & $\begin{array}{l}\text { Local businesses and cottage } \\
\text { industry }\end{array}$ & $\begin{array}{l}\text { Social network boosting } \\
\text { resilience of the community }\end{array}$ \\
\hline Sustainable transportation & Economic self-reliance & $\begin{array}{l}\text { Self-governance and volunteer } \\
\text { leadership capability }\end{array}$ \\
\hline Compact city approach & $\begin{array}{l}\text { Reserves of traditional skills } \\
\text { and crafts }\end{array}$ & $\begin{array}{l}\text { Reminiscence of indigenous } \\
\text { heritage and rural life, } \\
\text { connection with the soil }\end{array}$ \\
\hline $\begin{array}{l}\text { Traditional unmechanised } \\
\text { agricultural and livestock } \\
\text { farming methods }\end{array}$ & Traditional bazaar concept & $\begin{array}{l}\text { Self-managed social justice } \\
\text { system }\end{array}$ \\
\hline $\begin{array}{l}\text { Connection with flora and } \\
\text { fauna }\end{array}$ & Diverse and flexible places & $\begin{array}{l}\text { Interactive social setting } \\
\text { created from native art, } \\
\text { memory, expression, religion, } \\
\text { and identity }\end{array}$ \\
\hline Ability to recycle & Mixed-use buildings & Incremental housing \\
\hline
\end{tabular}

Source: authors.

This study generated empirical evidence about the capacity of informal communities to fabricate places that entail solutions to their needs that the government has failed to provide. It confirms the value of the self-help efforts by the inhabitants of informal settlements where the government and private sectors fail to provide housing solutions. In addition to informal settlements being a successful way to respond to the mass rural-tourban migration [22], they also exhibit many more sustainability features. They represent a spatio-cultural translation of the intangible cultural heritage that residents of informal communities bring along from their native villages and keep alive in the urban settings.

Through the process of incremental building and flexible adjustment to the urban surroundings, the dwellers of informal settlements create resilience $[61,65]$. This phenomenon is observed in France Colony, where the residents' approach to placemaking facilitated the establishment of sustainable liveability at a community level. However, not all features of the informal settlements represent sustainability, with ad hoc-ism evident in their built environment. The settlement depicts an image of a place of chaos, deprivation, and poverty due to constraints and challenges, such as poverty, insecure tenure, pollution, crime, lack of amenities, absence of local governance, fear of eviction, and many more.

The informal community struggles to preserve and practice cultural processes based on its rural values, memories, and experiences within the urban setting. As "values and meaning are not inherent in place; they are created, reproduced and defended" [27]. Residents of this informal settlement face numerous barriers/constraints in defending the values they seek to uphold in the urban setting. Upon immigration to cities, they had to reproduce the entire tangible cultural fabric that reflected their values and priorities from scratch. The extent to which they succeeded depends on numerous factors defining opportunities, imperatives, resourcefulness, and the availability of acceptable alternatives. Any characteristics of cultural values that did successfully translate into or positively influence their built environment through placemaking are important to comprehend 
and document. This needs to be done before they are lost, as the community finds it too inconvenient to defend and uphold and opts for assimilation, or worse still, gives up the effort to organise and improve its surroundings.

Concepts of self-reliance, resilience, and communal cohesion were found to exist to some extent in France Colony, as evident in the spatial data collected. However, the interface with the wider urban culture naturally constrains the extent of spread of indigenous regional cultural heritage within the informal settlement. Although many urban values are progressive and promote better lifestyles, our findings suggest some practices and a changed worldview threaten the loss of cultural heritage that promotes sustainable attributes. Some theorists also argue that due to poverty within informal settlements, having a choice, being creative, and applying their own aesthetical values are beyond the possibility of local residents [69], as they struggle on a day-to-day basis to make ends meet. Others deem informal settlements only as areas stricken with poverty $[21,46]$. However, in the current research, poverty is not seen as the defining factor of informal communities, but rather highlights many other aspects that distinguish these settlements in addition to the notion of them being poor. The research supports the ideology of Turner, who views the culture of an informal community as an antidote to their poverty [65]. Hence, the constraints hampering the process of cultural proliferation into spatial manifestation are discussed below. These constraints can limit the translation of cultural heritage into placemaking, leading to loss of heritage (see Figure 20).

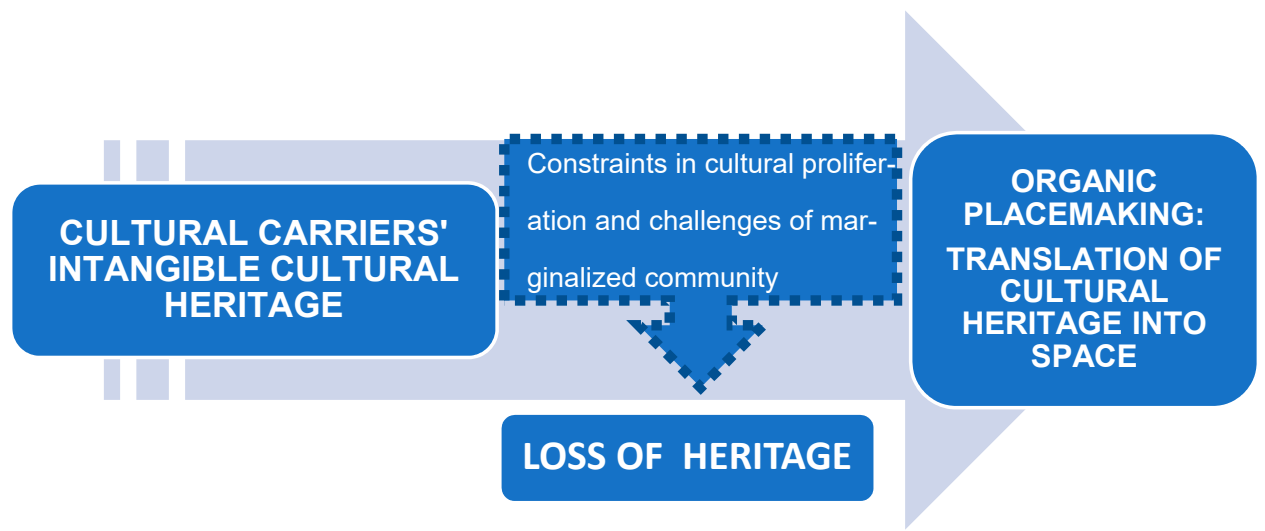

Figure 20. Relation between culture and organic placemaking. Source: authors.

Figure 20 broadly describes how the rural-urban migrants' intangible cultural heritage is expressed through organic placemaking. The inhabitants of informal settlements play the role of culture carriers, bringing intangible cultural heritage built around sustainability values from their ancestorial villages into the city. This heritage is translated into the spatial realm in the manifestation of informal settlements. However, where the translation of intangible culture into tangible spatial/physical fabric faces constraints/challenges, a loss of regional heritage and traditional practices supporting valuable sustainability concepts and practices occurs. A long list of constraints and challenges was recorded during the transect walks and spatio-cultural mapping conducted as part of the fieldwork. These include pollution and clogged waterways/naalah, issues of tenure security, the prevalence of petty crime and drugs, a disconnect from formally planned neighbourhoods, and the lack of quality control of self-built structures. It is anticipated that effective strategies devised to curtail the effects of some of these constraints through placemaking interventions would yield a significant impact in terms of sustainability and cultural preservation in such informal settlements and, consequently, the city.

The informal community has brought a rich intangible culture from the villages into the city and has created an impactful socio-spatial environment that distinguishes the residents of the informal settlement from the rest of the urban dwellers. However, the residents of informal settlements face constraints/barriers that prevent them from practicing 
traditional sustainable solutions to their problems. Being transplanted into an unfamiliar environment, many of these rural migrants appear to have lost a sense of belonging, leading to a loss of sense of responsibility for the surrounding built environment. This phenomenon is detected, for example, through disinterest in working towards improving the neighbourhood's places and built environment. Polluted alleys and collective disinterest are evidence for the need to instil a sense of ownership, reconnect with their community's roots rather than indulge in nostalgia, and nurture a sense of pride for the places of the neighbourhood that emerge from the cultural setting of the inhabitants [50].

The repelling elements of the informal settlements (as stated above) are their unhygienic conditions due to poor sewage, inadequate waste management systems, haphazard amenity networks (electrical and gas wiring and pipelines), and bad reputation due to social stigma and drug dealing. Pollution and poor waste management by people who are habitually engaged in self-help and waste recycling and disposal are uncanny. All these elements are closely entwined with the sense of ownership, lack of leadership, and insecurity of tenure issues in the settlement. However, Crooke [70] (p. 187) gives a different perspective on tenure. He explains that another lesson seems to be that people's residential security depends upon their enjoyment of rights to the use of settlement land, but not necessarily upon their owning it, and that in major parts of the Third World the very concept of land ownership is still alien, unfamiliar, and unnecessary.

According to Lefebvre [71], the right to the place (city) and tenure are two different aspects. He coined the idea of the right to the city in mid-20th century and summarised it as a "demand ... [for] a transformed and renewed access to urban life" [71] (p. 158). This understanding is aligned with the placemaking approach discussed in this study, as informal and formal communities co-create the city, or in other words, make the place, regardless of the tenure status and other land-related legalities. As an influx of people in rental houses and rooms, these tenants have less interest in resolving the long-term issues of the settlement. Moreover, constantly looking up to the state for the resolution of urban issues instead of doing this themselves has left informal settlements in disarray. A place without a sense of ownership by the people is thus unwelcoming, polluted, and chaotic.

Finding the means of establishing a sense of ownership amongst the inhabitants, creating governance strategies to encourage community participation, and reviving the spirit of self-reliance, which is an integral part of the cultural values of the people, are the key to improve the living standards within the community. This would potentially have a direct impact on the spatial outlook of the place. In turn, it could provide an attractive village setting within the city of Islamabad to be visited, cherished, and experienced by urbanites. It could eventually serve as an interactive interface promoting rural cultural proliferation into the urban environment. By removing constraints and barriers to such interaction, these informal settlements can be envisioned as educational platforms for sustainable liveability promoting culturally appropriate and established values and practices. These informal settlements can serve as tourist destinations, promoting traditional crafts, cuisines, ancient rituals, and attire, and revive ceremonies and festivals of the rural areas of Pakistan. Livelihood opportunities could thus be created for the people capitalising on their ancestral crafts and skills, while inculcating pride and ownership of their heritage. It is not a matter of saying that informal settlements are the ultimate solution to mass urbanisation; it is making a case for exploiting their full potential rather than erasing or redeveloping the settlements. It is also to make the case for recognising the placemaking abilities of the informal settlement residents who are making France Colony a more sustainable place, rather than evicting the marginalised and vulnerable people who have made it their home.

\section{Concluding Remarks}

The fieldwork in France Colony, Islamabad, collected empirical data on the presence of sustainability elements embedded in the intangible cultural heritage of the migrants settled in this informal settlement. Inhabitants of the informal settlement have thus become culture carriers from the regional areas of Pakistan and have been implanted in the midst 
of the modernist planned city of Islamabad. The place they self-created from memories, values, and ancestral techniques has manifold sustainability facets, including environmental elements embedded in vernacular architecture, the use of local and recycled materials, sustainable transportation, compactness, unmechanised food practices, the ability to recycle and connect with flora and fauna; economic characteristics, including practicing micro-economic and entrepreneurial activities, local and cottage industries, self-reliance, traditional crafts and bazaars, mixed-used buildings and diverse and flexible places; as well as social resilience through cultural display, indigenous lifestyles and incremental building, connection with the soil, social networks, self-governance and self-justice, and overall interactive social settings.

This study challenged the binary discourse of formal-informal settlements by exploring urban reality through the lens of placemaking in the case study. It attempted to look beyond perceiving the informal settlements as "disorderly, unclean and illegitimate rather as places created by the people" [26]. Valuable sustainable assets latent in the spatiocultural system of the informal settlements were revealed and the hypothesis that cultural heritage entails sustainability was shown to be true. The roots of sustainability come from the local soil and through the informal settlements there is greater probability of acceptance, ownership, and eventually assimilation into the lifestyle of the urban dwellers, promising a better future.

The analysis provided an alternative perspective of urban informal settlements by showing them as places of rural remnants, reservoirs of regional cultural heritage, and spaces entailing traditional sustainable elements brought to the urban realm by rural migrants. It provided a rare insight into the reality of informal settlements existing within the formally planned city of Islamabad. By employing the transect walk method and mapping, the study explored the existing place characteristics, and traditional and organic placemaking strategies adopted by residents in France Colony, the urban informal settlement in the heart of Islamabad. It highlighted the specific sustainability qualities of France Colony, ranging from compactness of development, to sustainable modes of transportation, to the use of recycled materials. It documented how these qualities have contributed to developing a self-reliant micro-economy catering to diverse users, capitalising on traditional skills and flexibility to enhance cultural resilience and self-management.

France Colony's unique spatial characteristics resulting from organic placemaking over the years reflect the richness and diversity of the socio-cultural systems operating in the informal settlements of Islamabad. This study offers an insight into the role of organic placemaking, driven by everyday life routines influenced by rural values, behaviour, and lifestyle, and plays into shaping physical spaces and forms in informal settlements. Its findings highlight the task for urban planners and policymakers to promote placemaking practices that enhance sustainability and to remove barriers to the translation of sustainable rural traditions. The study also supports the idea that informal settlements can provide socio-spatial context wherein strong, vibrant, and resilient communities emerge. Though the study only analysed the present spatial setting of the selected informal settlement, it also paved the way for future research related to spatial morphology and evolution of the built environment over time in relation to migration patterns and transforming cultural influences.

Author Contributions: All authors conceptualised this study; R.S. collected and analysed the empirical data and drafted the article; all authors made contributions throughout all sections. All authors have read and agreed to the published version of the manuscript.

Funding: Ramisa Shafqat received an Australian Postgraduate Research Scholarship.

Institutional Review Board Statement: The study was approved by the Human Research Ethics Committee of Curtin University.

Informed Consent Statement: Informed consent was obtained from all subjects involved in the study. 
Data Availability Statement: Further information regarding data is available upon request from the corresponding author.

Conflicts of Interest: The authors declare no conflict of interest.

\section{References}

1. Cresswell, T. Place: A Short Introduction; Blackwell: Oxford, UK, 2004.

2. Friedmann, J. Reflections on place and place-making in the cities of China. Int. J. Urban Reg. Res. 2007, 31, 257-279. [CrossRef]

3. Lombard, M. Making a Place in the City: Place-Making in Urban Informal Settlements in Mexico. Ph.D. Thesis, University of Sheffield, Sheffield, UK, 2009.

4. Relph, E. Place and Placelessness; Pion: London, UK, 1976.

5. Alexander, C.; Ishikawa, S.; Silverstein, M. A Pattern Language: Towns, Buildings, Construction; Oxford University Press: New York, NY, USA, 1977.

6. Sofield, T.; Guia, J.; Specht, J. Organic 'folkloric' community driven place-making and tourism. Tour. Manag. 2017, 61, 1-22. [CrossRef]

7. Courage, C.; Borrup, T.; Jackson, M.R.; Legge, K.; Mckeown, A.; Platt, L.; Schupbach, J. (Eds.) The Routledge Handbook of Placemaking; Routledge: Abingdon, UK, 2021.

8. Shibley, R.G.; Schneekloth, L.H. Placemaking: The Art and Practice of Building Communities; Wiley: New York, NY, USA, 1995.

9. Santos, N.; Costa, J.P. Placemaking and climate change adaptation: New qualitative and quantitative considerations for the "Place Diagram". J. Urban. Int. Res. Placemaking Urban Sustain. 2017, 10, 356-382. [CrossRef]

10. Puspitasari, P.; Djunaedi, A.; Putra, H.; Shri, A. The significance of preserving the genius loci in nurturing historic-religious urban settlement case study: Kampung Luar Batang (Jakarta, Indonesia). J. Tata Loka 2011, 13, 197-204.

11. Dessein, J.; Battaglini, E.; Horlings, L. Cultural Sustainability and Regional Development: Theories and Practices of Territorialisation; Routledge: Abingdon, UK, 2015.

12. Kellett, P. The construction of home in the informal city. J. Romance Stud. 2002, 2, 17-31. [CrossRef]

13. Lombard, M. Constructing ordinary places: Place-making in urban informal settlements in Mexico. Prog. Plan. 2014, 94, 1-53. [CrossRef]

14. Horlings, L.G. Values in place: A value-oriented approach toward sustainable place-shaping. Reg. Stud. Reg. Sci. 2015, 2, 257-274. [CrossRef]

15. Evans, P. (Ed.) Liveable Cities; University of California Press: Berkeley, CA, USA, 2002.

16. Project for Public Spaces (PPS). What Is Placemaking? 2020. Available online: https://www.pps.org/article/what-is-placemaking (accessed on 1 May 2021).

17. Massey, D. Space, Place, and Gender; University of Minnesota Press: Minneapolis, MN, USA, 1994.

18. Appleton, J. Values in Sustainable Development; Routledge: London, UK, 2014.

19. UN-Habitat. The Challenge of the Slums: Global Report on Human Settlements 2003. Available online: https://www.un.org/ ruleoflaw / files /Challenge\%20of\%20Slums.pdf (accessed on 18 June 2021).

20. Neuwirth, R. Shadow Cities: A Billion Squatters, A New Urban World; Routledge: New York, NY, USA, 2005.

21. Gaskell, M. Slums; Leicester University Press: Leicester, UK, 1990.

22. Mangin, W.P.; Turner, J.F.C. Benavides and the barriada movement. In Shelter and Society; Oliver, P., Ed.; Barrie \& Jenkins: London, UK, 1969; pp. 127-136.

23. UN-Habitat. Placemaking Toolkit: Designing People Places: A Toolkit for Communities and Designers to Design and Implement Public Spaces and Buildings in Palestine. 2020. Available online: https://unhabitat.org/sites/default/files/2020/04/ placemaking_toolkit_eng_27042020.pdf (accessed on 15 January 2021).

24. UN-Habitat. Addressing the Most Vulnerable First: Pro-Poor Climate Action in Informal Settlements. 2018. Available online: https://unhabitat.org/sites/default/files/2019/05/pro-poor_climate_action_in_informal_settlements-.pdf (accessed on 18 March 2020).

25. Silva, P. Not so much about informality: Emergent challenges for urban planning and design education. Sustainability 2020, 12, 8450. [CrossRef]

26. Lombard, M. Using auto-photography to understand place: Reflections from research in urban informal settlements in Mexico. Area 2013, 45, 23-32. [CrossRef]

27. Cresswell, T. In Place/Out of Place; University of Minnesota Press: London, UK, 1996.

28. Doxiadis, C. Islamabad: The creation of a new capital. Town Plan. Rev. 1965, 36, 1-28. [CrossRef]

29. Kara, H. Creative Research Methods in the Social Sciences: A Practical Guide; Policy Press: Bristol, UK, 2015.

30. Yin, R. Case Study Research: Design and Methods, 2nd ed.; Sage Publishing: Beverly Hills, CA, USA, 1994.

31. Rashid, Y.; Rashid, A.; Warraich, M.A.; Sabir, S.S.; Waseem, A. Case study method: A step-by-step guide for business researchers. Int. J. Qual. Methods 2019, 18,1-13. [CrossRef]

32. Jacobs, J. The Death and Life of Great American Cities; Vintage Publishing: New York, NY, USA, 2016.

33. Whyte, W.H. The Social Life of Small Urban Spaces; Project for Public Spaces: New York, NY, USA, 2001.

34. Mead, M. Continuities in Cultural Evolution; Routledge: New York, NY, USA, 1999. 
35. Project for Public Spaces (PPS) Placemaking and Place-led Development. Available online: https://www.pps.org/reference/ placemaking-and-place-led-development-a-new-paradigm-for-cities-of-the-future/ (accessed on 18 June 2021).

36. Hebbert, M. Figure-ground: History and practice of a planning technique. Town Plan. Rev. 2016, 87, 705-728. [CrossRef]

37. Steuteville, R.; Langdon, P. New Urbanism: Best Practices Guide; New Urban News Publications: Ithaca, NY, USA, 2009.

38. Diedrich, L.; Lee, G.; Braae, E. The traveling transect. In Experiments in Design Research; Proceedings of Nordes 2013, Online Proceedings, 9-12 June 2013; Brandt, E., Ehn, P., Johansson, T.D., Reimer, M.H., Markussen, T., Vallgårda, A., Eds.; Available online: http:/ / www.nordes.org/opj/index.php/n13/article/download/274/349 (accessed on 18 June 2021).

39. Diedrich, L.; Lee, G.; Braae, E. The Transect as a Method for Mapping and Narrating Water Landscapes: Humboldt's Open Works and Transareal Travelling. Nanocrit 6. 2014. Available online: http:/ /www.nanocrit.com/issues/6-2014/transect-methodmapping-narrating-water-landscapes-humboldts-open-works-transareal-travelling (accessed on 8 September 2019).

40. Melemis, S.; Tixier, N.; Brayer, L. Urban transects: The place of research/the research of place. In Proceedings of the ARCC/EAAE 2010 International Conference on Architectural Research, Washington, DC, USA, 24-26 June 2010; Architectural Research Centers Consortium: Washington, DC, USA, 2010.

41. Catalytic Community. CatComm. Available online: http:/ / catcomm.org (accessed on 22 February 2018).

42. Corner, J. The agency of mapping: Speculation, critique and invention. In Mappings; Cosgrove, D., Ed.; Reaktion Books: London, UK, 1999; pp. 213-252.

43. Cultural Mapping Toolkit. Partnership between 2010 Legacies Now and Creative City Network of Canada. Available online: https://theavarnagroup.com/wp-content/uploads/2018/01/cultural_mapping_toolkit.pdf (accessed on 13 May 2020).

44. Duxbury, N.; Garrett-Petts, W.F.; MacLennan, D. (Eds.) Cultural Mapping as Cultural Inquiry; Routledge: New York, NY, USA, 2015.

45. Sheikh, F. A France We Must Visit. The Friday Times. 2018. Available online: https:/ /www.thefridaytimes.com/a-france-wemust-visit/ (accessed on 25 April 2021).

46. Davis, M. Planet of Slums; Verso: London, UK, 2006.

47. Zaman, M. Description of the Pakistani context. In The Codes of the Street in Risky Neighborhoods: A Cross-Cultural Comparison of Youth Violence in Germany, Pakistan, and South Africa; Heitmeyer, W., Howell, S., Kurtenbach, S., Rauf, A., Zaman, M., Zdun, S., Eds.; Springer: Cham, Switzerland, 2019. [CrossRef]

48. Capital Development Authority Islamabad Pakistan. Available online: http://www.cda.gov.pk/ (accessed on 23 March 2017).

49. Zafar, Z.I.; Waheed, A.; Javaid, B. Addressing the affordable housing challenges for urban poor in Pakistan. Glob. Soc. Sci. Rev. 2019, 4, 416-433.

50. Carmona, M. Public Places Urban Spaces: The Dimensions of Urban Design, 2nd ed.; Routledge: New York, NY, USA, 2003.

51. Organisation for Economic Co-operation and Development (OECD) Compact City Policies: A Comparative Assessment. 2012. Available online: https://www.oecd.org/cfe/regionaldevelopment/50524895.pdf (accessed on 29 October 2018).

52. Yousafzai, M.T.; Nawaz, M.; Xin, C.; Tsai, S.-B.; Lee, C.-H. Sustainability of waste picker sustainopreneurs in Pakistan's informal solid waste management system for cleaner production. J. Clean. Prod. 2020, 267, 121913. [CrossRef]

53. Lynch, K. The Image of the City; MIT Press: Cambridge, MA, USA, 1960.

54. Dhiman, S.; Marques, J. (Eds.) Spirituality and Sustainability: New Horizons and Exemplary Approaches; Springer: Cham, Switzerland, 2016.

55. Blunt, A.; Dowling, R. Home; Routledge: Abingdon, VA, USA, 2006.

56. Tamminga, K.; Knüvener, T. On sustainable I sustaining city streets. Sustainability 2021, 13, 1895. [CrossRef]

57. Giddens, A. Studies in Political and Social Theory; Hutchinson: London, UK, 1977.

58. Steadman, P. The Evolution of Designs: Biological Analogy in Architecture and the Applied Arts; Cambridge University Press: Cambridge, UK, 1979.

59. Goldwyn, J. Resilience, Self-Reliance and Sustainability. 2020. Available online: https://www.watg.com/resilience-in-an-era-ofuncertainty-self-reliance-and-sustainability / (accessed on 1 May 2021).

60. Ahfeldt, G.M.; Pietrostefani, E. The Compact City in Empirical Research: A Quantitative Literature Review; SERC Discussion Papers (SERCDP0215); Spatial Economics Research Centre, London School of Economics and Political Science: London, UK, 2017; Available online: http:/ / eprints.lse.ac.uk/83638/ (accessed on 2 February 2020).

61. Turner, J. Housing as a verb. In Freedom to Build: Dweller Control of the Housing Process; Turner, J., Fichter, R., Eds.; Collier-Macmillan: New York, NY, USA, 1972; pp. 148-175.

62. Çahantimur, A.; Beceren Öztürk, R.; Sevgi, S. Compact city and traditional housing areas for urban sustainability: A case study-Bursa, Turkey. Trans. Ecol. Environ. 2015, 194, 59-68.

63. Wen, L.; Kenworthy, J.; Guo, X.; Marinova, D. Solving traffic congestion through street renaissance: A perspective from dense Asian cities. Urban Sci. 2019, 3, 18. [CrossRef]

64. Elewa, A.K.A. Flexible public spaces through spatial urban interventions, towards resilient cities. Eur. J. Sustain. Dev. 2019, 8, 152-168. [CrossRef]

65. Turner, J.F.C. Barriers and channels for housing development in modernising countries. J. Am. Inst. Plan. 1967, 38, 167-180. [CrossRef] 
66. Salman, M. Sustainability and vernacular architecture: Rethinking what identity is. In Urban and Architectural Heritage Conservation within Sustainability; Hmood, K., Ed.; InTech Open: London, UK, 2018; Available online: https: / / www.intechopen.com/books/urban-and-architectural-heritage-conservation-within-sustainability/sustainabilityand-vernacular-architecture-rethinking-what-identity-is (accessed on 10 May 2020).

67. Saeed. Folk Heritage of Pakistan: Glimpses into Cultural Diversity; The National Institute of Traditional and Folk Heritage: Islamabad, Pakistan, 2016.

68. Acciona. Art and Sustainability. 2019. Available online: https://www.activesustainability.com/sustainable-development/artand-sustainability/ (accessed on 18 June 2021).

69. Hernandez, J. Cultural expressions and public space in informal settlements (popular habitat) in Colombia. In Proceedings of the 44th Annual Conference of the Society for Latin American Studies, Liverpool, UK, 28-30 March 2008.

70. Crooke, P. Popular housing supports and the urban housing market. In People, Poverty E Shelter: Problems of Self-Help Housing in the Third World; Skinner, R.J., Rodell, M.J., Eds.; Methuen: London, UK, 1983.

71. Lefebvre, H. The Production of Space; Blackwell: Oxford, UK, 1991. 